\title{
Stratigraphy of a Lateglacial lake basin sediment sequence at Turret Bank, upper Glen Roy, Lochaber: implications for the age of the Turret Fan
}

Article

Accepted Version

Creative Commons: Attribution-Noncommercial-No Derivative Works 4.0

Lowe, J. J., Palmer, A. P., Carter-Champion, A., MacLeod, A., Ramírez-Rojas, I. and Timms, R.G.O. (2017) Stratigraphy of a Lateglacial lake basin sediment sequence at Turret Bank, upper Glen Roy, Lochaber: implications for the age of the Turret Fan. Proceedings of the Geologists' Association, 128 (1). pp. 110-124. ISSN 0016-7878 doi:

https://doi.org/10.1016/j.pgeola.2016.12.008 Available at https://centaur.reading.ac.uk/77196/

It is advisable to refer to the publisher's version if you intend to cite from the work. See Guidance on citing.

Published version at: http://dx.doi.org/10.1016/j.pgeola.2016.12.008

To link to this article DOI: http://dx.doi.org/10.1016/j.pgeola.2016.12.008

Publisher: Elsevier

All outputs in CentAUR are protected by Intellectual Property Rights law, including copyright law. Copyright and IPR is retained by the creators or other copyright holders. Terms and conditions for use of this material are defined in the End User Agreement. 


\section{www.reading.ac.uk/centaur}

\section{CentAUR}

Central Archive at the University of Reading

Reading's research outputs online 
Stratigraphy of a Lateglacial lake basin sediment sequence at Turret Bank, Upper Glen Roy, Lochaber: implications for the age of the Turret Fan

Lowe, J. J. ${ }^{1 \dagger}$, Palmer, A.P. ${ }^{1}$, Carter-Champion, A. ${ }^{1}$, MacLeod, A. M. ${ }^{1}$, Ramírez-Rojas, I. ${ }^{1,2}$, Timms, R. G. O. ${ }^{1}$

${ }^{1}$ Centre for Quaternary Research, Department of Geography, Royal Holloway University of London, Egham, Surrey. TW20 0EX.

${ }^{2}$ now at Pablo de Olavide University, Ctra. de Utrera, 1, 41013 Sevilla, Spain.

${ }^{\dagger}$ Corresponding author: John Lowe j.lowe@rhul.ac.uk

\section{Abstract:}

New lithostratigraphical, pollen-stratigraphical and tephrostratigraphical data are presented for a sediment sequence at Turret Bank, a site that lies close to the confluence of the River Turret with the River Roy in Lochaber, the western Scottish Highlands. The site is also adjacent to the inner margin of a major gravel fan, the Glen Turret Fan, the age of which has been debated and has a crucial bearing on the overall sequence of events in Glen Roy, especially concerning the maximum limit of Loch Lomond Readvance (Younger Dryas) ice. Several lines of evidence point to the sediment sequence at Turret bank having been wholly deposited during the Loch Lomond Stadial-early Holocene transition: (i) the pollen sequence is typical for this transitional period; (ii) varved deposits preserved in the sequence bear a strong resemblance to mid-Stadial varves in a regional master varve scheme for Glen Roy and vicinity (the Lochaber Master Varve Chronology); and (iii) an early Holocene tephra the Askja-S Tephra - is preserved within the sequence. Some limitations with the new data are considered, but it is concluded that the coherent integration of lithostratigraphic, geomorphological, pollen-stratigraphical and tephrostratigraphical data point to the likelihood that Loch Lomond Readvance ice extended to the inner margin of the Glen Turret Fan, and that the fan was probably constructed by glacial meltwaters at this time.

Keywords: Lithofacies analysis; varve deposits; pollen stratigraphy; Askja-S Tephra; limits of the Loch Lomond Readvance in Glen Roy. 


\section{Introduction}

The Turret Fan is one of a series of large gravel fans that occupy Glen Roy, the majority of which occur at the mouths of tributary valleys (Cornish, 2017). That they are associated with the decay stages of former glaciers in the area is not contested, but the age of the deposits has fueled debate, and especially so in the case of the Turret Fan. This feature differs from the others, in that it abuts arcuate terminal moraine ridges (Figure 1c). Some researchers argue that the moraines and the fan deposits are contemporaneous, and assign both to the Loch Lomond Readvance (Sissons and Cornish, 1983; Benn and Evans, 2008; Sissons, 2017), though there are differences of opinion on the source of the ice. Others consider the fan to have been formed during or shortly after the retreat of the Late Devensian ice sheet (Peacock, 1986; Boston et al., 2013; Boston and Lukas, 2017). The lines of evidence employed on both sides of the argument are essentially based on geomorphological and sedimentological observations: no independent chronological information is available that directly dates the fan deposits. Lowe and Cairns (1991), however, reported the results of a pollen-stratigraphic study of a sediment sequence preserved beneath fluvial deposits on the floor of the Turret valley, from a site that lies inside (up-valley from) the terminal moraine, and hence post-dates this feature (Figure 1). The sequence was interpreted as having accumulated during the Stadial-Holocene transition, on the basis of pollen stratigraphy, and this evidence was in turn used to support the view that the terminal moraine and Turret Fan were formed during the Loch Lomond Stadial. However, sampling limitations compromised the results presented by Lowe and Cairns (1991), mainly because hand-operated coring devices were employed, which failed to penetrate stiff sediments in the lower part of the sequence. An open Dutch gouge was therefore used to recover some of the basal sediments from which pollen-stratigraphical data were obtained, but those data suggested evidence of contamination by downward transport of pollen, casting further doubt on the results. Moreover, the argument that the oldest sediments in the sequence were of StadialHolocene transition age rests on the 'absence of evidence' of older (Lateglacial Interstadial) deposits, which could not be demonstrated convincingly. Here we present the results of new investigations of the Turret Bank site, based on cores retrieved using a mechanicallypowered coring device, detailed analysis of the lithological characteristics of the basal sediments, and new pollen-stratigraphical and tephrochronological data. The results clarify a number of aspects about the nature and age of the deposits preserved at Turret Bank.

\section{Local context}

The Turret Fan today occupies an area of $0.35 \mathrm{~km}^{2}$ at the confluence of the Rivers Turret and Roy. Both rivers have heavily dissected the fan and a series of terraces, formed mainly by the Roy (Figure 2), reveal a history of progressive downcutting. The fan originally 

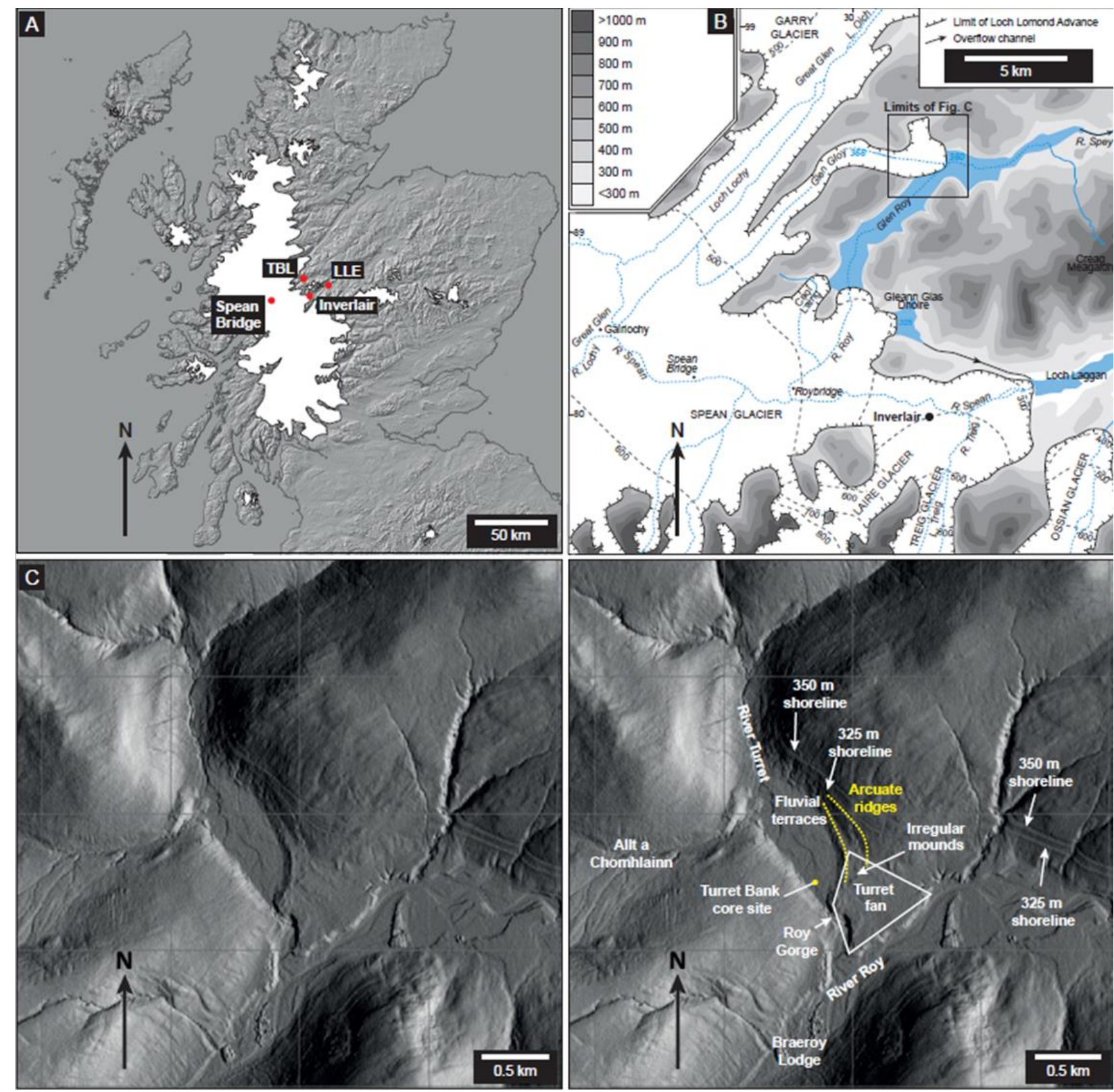

Figure 1. Location detail. 1a. Location of the study area and of some key features referred to in text, in particular the generalised maximum glacial limits of the Loch Lomond Readvance. TBL Turret Bank site. LLE - Loch Etteridge site. 1b. The study area showing maximum glacier limits in Glen Roy and vicinity, after Sissons (2017). $1 \boldsymbol{c}$ and $\mathbf{1 d}$. Geomorphological features close to the Turret-Roy confluence ( $1 \mathrm{~km}$ grid squares), showing location and form of key features referred to in text (unmarked in 1c). The prominent parallel lines on the hillside are the 325 and $350 \mathrm{~m}$ shorelines. Note that the $325 \mathrm{~m}$ shoreline is clearly marked on the NE side of Glen Turret, but fades in the vicinity of the up-valley limit of the arcuate moraine ridges, whereas the $350 \mathrm{~m}$ shoreline continues further up the Turret valley. The NEXTMap DEMs shown here are provided courtesy of the Natural Environment Research Council (NERC) and Intermap Technologies. 
extended across the whole valley, and hence blocked the course of the rivers, which subsequently eroded the deposits (Cornish, 2017). A number of exposures reveal that the fan is formed of mainly gravels, in places exceeding $20 \mathrm{~m}$ in thickness, and formed of beds that dip sub-horizontally towards the course of the Roy at low angles. They have been

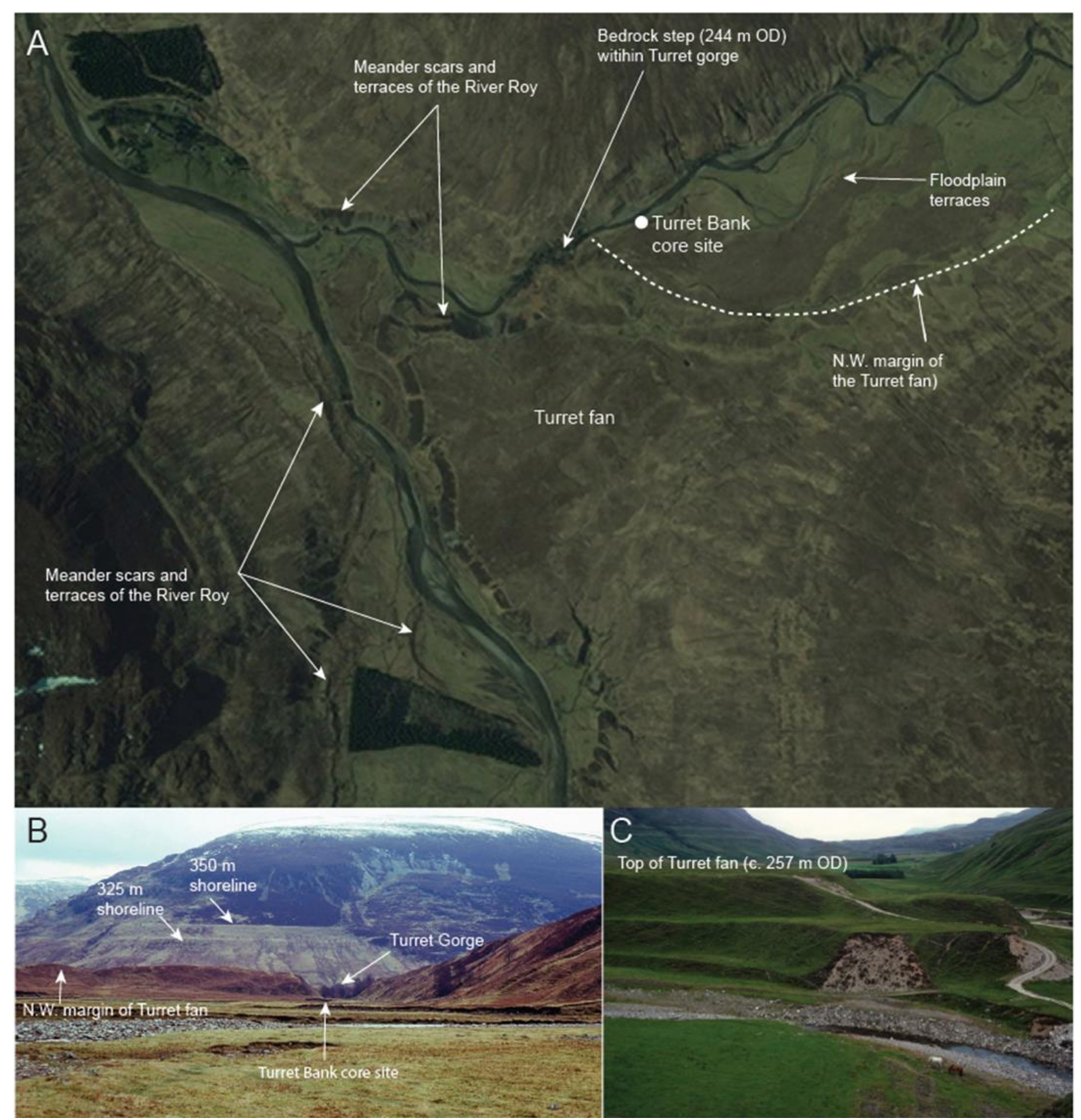

Figure 2. A. Google Earth image of Turret-Roy confluence illustrating the extent of incision into, and removal of material from, the Turret Fan. See text for further detail. B. Photograph facing SE taken from the present floodplain of the River Turret (foreground) showing the steep 'inner' (NW) margin of the Turret Fan, the opening to the Turret Gorge and the location of the Turret Bank core site. C. View eastwards from the right bank of the River Turret (foreground), close to its confluence with the River Roy, showing fluvial terraces cut into the Turret Fan, the surface of which is at $\sim 257 \mathrm{~m}$ OD in this locality. Photographs B and C supplied by Roger Cornish. See text for further detail. 
variously interpreted as consisting of subaerial gravel bars (Peacock, 1986), turbidites and mass flows (Benn and Evans, 2008), grounding line fans (Boston et al., 2013; Boston and Lukas, 2017) and Hjulström-type fans generated by torrential high density sediment pulses (Cornish, 2017). On the fan surfaces, at distal edges, thick sequences of laminated silts and clays $\sim 1$ to $1.5 \mathrm{~m}$ thick are exposed, some of which contain glaciolacustrine varves. These have been shown to be of Loch Lomond Stadial age, and were deposited when the icedammed lakes stood at the 325 and 350 m levels (Palmer et al., 2010, 2012).

Within the Turret Valley, the north-western margin of the fan is delimited by a very steep bluff that curves across the floor of the valley (Figure 2B). Close to this margin, the surface of the fan is hummocky, including several ridges that are clearly aligned and merge with lateral ridges that extend westwards on the northern flank of the Turret (Figure 1c). These geomorphological features collectively appear to mark the terminus of a former glacier, and the fact that the features merge with the Turret Fan has led some to propose that they were formed contemporaneously. The surface of the Turret Fan declines gradually from $\sim 270 \mathrm{~m}$ near the hummocky mounds referred to above, to $253-251 \mathrm{~m}$ towards its southern extremity, and would therefore have been mostly submerged by the $260 \mathrm{~m}$ lake, an observation taken by some to reinforce the argument that the fan was formed during the Loch Lomond Stadial, a matter we return to in a later section of this paper. Further details on the debate about the age of the Turret Fan, the sedimentology of the deposits of which it is composed, and the local and regional geomorphological context can be found in Boston \& Lukas (2017), Cornish (2017) and Palmer and Lowe (2017).

The key focus of this contribution is a sediment sequence preserved at Turret Bank, located on the left bank of the River Turret, approximately $150 \mathrm{~m}$ upstream from the steep bluff that marks the NW extremity of the fan in lower Glen Turret, at grid point NN 3372593379 (Figures 1 and 2). The floor of the Turret is generally flat, consisting of fluvial terraces lying mostly between $\sim 260-245 \mathrm{~m}$ in altitude. There is no trace of the $260 \mathrm{~m}$ Parallel Road in this valley, but the 325 and $350 \mathrm{~m}$ shorelines are clearly marked. The river presently exits the Turret Valley through a gully cut into the fan on its southern margin Figure 2B), before joining the River Roy to the north of Braeroy Lodge. Within this gully the river has eroded down to exposed bedrock at the river bed, which appears to form a base level for floodplain deposits upstream. This bedrock surface has an altitude of $244.44 \mathrm{~m} \mathrm{OD}$, an observation that is critical to the interpretation of the Turret Bank sequence, discussed below. 
The river at Turret Bank has incised into flood-plain deposits, which have a surface altitude of $\sim 250 \mathrm{~m}$ in this vicinity, exposing organic silts with a distinct macrofossil-rich layer, containing tree roots, cones, seeds and leaves. Coring from the surface of an erosional bench cut into this river bank exposure by Lowe and Cairns (1991) penetrated through the surface organic deposits to a depth of $8 \mathrm{~m}$. The top $4 \mathrm{~m}$ were cored using a Russian sampler, but the lower sediments proved difficult to penetrate using this device, and recourse had to be made to the use of an open-face Dutch gouge sampler of internal diameter $6 \mathrm{~cm}$, while the lowermost recovered metre could only be penetrated using a Dutch gouge of $3 \mathrm{~cm}$ internal diameter (Lowe and Cairns, 1991). No further penetration was possible using the samplers available.

The uppermost $3 \mathrm{~m}$ of the sediment sequence consisted of peat and organic silts, which were interrupted by occasional bands of silts or grit, below which organic-stained clay extended to around $7 \mathrm{~m}$ depth and graded gradually into micaceous silts with some sand layers. In parts these deposits were faintly laminated, although the structures were not well preserved. Below this, the lowermost metre in the sequence consisted of rhythmically bedded silts and clays, becoming stiffer and harder to penetrate towards the base; further penetration was prevented by extremely stiff coarse sand. These basal beds were deformed, presumably by the coring operation.

Pollen data were analysed for 25 sampled horizons extending between 550 and $790 \mathrm{~cm}$ depth in the sequence, and these showed a typical early Holocene pollen succession with, from the base, relatively high levels of Rumex and Lactuceae (formerly Compositae) pollen, giving way to a marked Empetrum phase, in turn succeeded by spectra dominated by Betula and Corylus. Juniperus pollen were also recorded, but percentages for this taxon were much lower than in early Holocene sequences reported from several other sites in the near vicinity (Lowe and Cairns, 1991; Kelly et al., 2016). Although this sequence bears the hallmarks of a typical early Holocene succession, a number of limitations compromise interpretation of the data, the key ones being:

- The lowermost silts/sands in the sequence were expected to have little or no pollen, or to be dominated by herbaceous taxa, but instead contained relatively high levels of Betula, Alnus and Corylus; these were considered to be signs of downward contamination, possibly as a result of the use of an open gouge sampler, which raises questions about the integrity of other components of the pollen-stratigraphic data. 
- The relatively low values for Juniperus pollen are unusual for an early Holocene sequence in this part of Scotland, and may reflect the influence of local factors affecting pollen recruitment, possibly a strong through-flow of water, since the core site is located close to where the stream exits the basin. If this was indeed the case, then it could have been a factor that distorted other pollen spectra in the sequence.

- A problem with the use of an open gouge sampler is that sedimentary structures can become distorted, especially in soft materials like clays and silts. Hence some fine laminations could have been obscured.

- Since it cannot be demonstrated that the base of the sediment sequence was reached, the possibility that older organic layers lie beneath the cored sequence cannot be discounted.

In view of these limitations, significant doubt is cast over interpretations based on this record, and given that the site occupies a critical location with respect to the Turret Fan, reinvestigation of the sequence was considered necessary, and was initiated in 2014. Furthermore, since the initial work conducted by Lowe and Cairns, cryptotephra stratigraphy has emerged as an important new chronological tool for dating Lateglacial and early Holocene deposits in Scotland (Matthews et al., 2011; Brooks et al., 2012; Davies, 2015; Lowe, 2016; Timms et al., 2016), and an investigation of the Turret Bank sequence for the presence of cryptotephra layers was therefore also attempted.

\section{Aims and objectives}

The overall aim of this new investigation was to establish whether the sequence at Turret Bank provides definitive information on the age of the Turret Fan. To achieve this, or at the very least to generate less contentious data than those presented by Lowe and Cairns (1991), the following objectives were set:

- To employ a power-driven coring device that might allow deeper penetration of the sediment sequence.

- To ensure capture of undisturbed sediment cores, allowing the finer details of the sedimentary sequence to be examined and analysed.

- To establish whether varved deposits are preserved in the sequence.

- To undertake new pollen-stratigraphic studies, to evaluate in more detail the limitations of the original pollen record.

- To examine the sequence for cryptotephra content, and to establish the age of any tephra layers detected. 
The methods employed to achieve these objectives are summarised next.

\section{Methods}

Two sediment cores were recovered from the northern bank of the Turret river (at grid point NN 33725 93379) using an Eijkelkamp Stitz system with a core barrel $100 \mathrm{~cm}$ in length and $5 \mathrm{~cm}$ internal diameter, and driven by a Cobra TT percussion motor. Penetration started from a ground surface of $246.91 \mathrm{~m}$ OD. Altitudes of the entry points of the boreholes and of adjacent features, including the rock step in the Turret gorge alluded to earlier, were determined using a Topcon Total Station $(+/-2 \mathrm{~cm})$. Scores were collected from two adjacent boreholes; successive core drives were overlapped by $0.5 \mathrm{~m}$ to ensure complete recovery of the sediment sequence. Tie-points between the sediment cores were determined using composite lithological data, based on visual examination of the main sedimentary units, supplemented by measurements of magnetic susceptibility and loss-on-ignition variations. For sediment descriptions, standard protocols were employed for grain size classifications, confirmed using a Malvern Mastersizer 2000 with a Hydro MU unit on the less than $2 \mathrm{~mm}$ fraction of the sediment units. For detailed examination of the finer sedimentary structures, thin sections were prepared using standard preparation procedures (see Palmer et al., 2008; Bendle et al., 2015) and analysed using a Leica M205 petrological stereo-zoom microscope. Organic content was estimated by loss-on-ignition (LOI) determination with a combustion temperature of $550{ }^{\circ} \mathrm{C}$. Volume specific magnetic susceptibility was measured using a Bartington MS2C core loop sensor and MS2 meter at 1 $\mathrm{cm}$ resolution.

For pollen preparations, samples of 1 to $2 \mathrm{~cm}^{3}$ in volume were deflocculated using $1 \%$ sodium pyrophosphate $\left(\mathrm{Na}_{4} \mathrm{P}_{2} \mathrm{O}_{7}\right)$, then sieved through coarse (125 $\mu \mathrm{m}$ mesh) and fine (10 $\mu \mathrm{m}$ mesh) sieves before being rinsed with deionised water. The centrifuged residues were treated with $10 \%$ hydrochloric acid to dissolve carbonate materials followed by immersion in sodium polytungstate $\left(3 \mathrm{Na}_{2} \mathrm{WO}_{4} .9 \mathrm{WO}_{3} . \mathrm{H}_{2} \mathrm{O}\right)$ of specific gravity $2.0 \mathrm{~g} \mathrm{~cm}^{-3}$ to float and recover fine-grained material. The recovered material was subsequently rinsed thoroughly in deionised water, dehydrated and treated using the Erdtman's acetolyis procedure (Hesse and Waha, 1989). The final residues were mounted on slides using glycerine and pollen identifications made using a binocular Olympus microscope at x400 magnification, with difficult grains examined at x1000 magnification.

Preparations for tephra detection, extraction of glass particles and mounting of materials for geochemical analysis followed the protocols established by Turney et al. $(1997 ; 2004)$ with 
the adaptions introduced by Blockley et al. (2005). Identifications were made using an Olympus $\mathrm{CH}-2$ microscope with magnifications between $\mathrm{x} 100$ and $\mathrm{x} 400$. Glass particles extracted from peak shard levels were analysed using electron microprobe micro-analysis

A.

\begin{tabular}{|c|c|c|c|c|c|c|c|c|c|c|}
\hline Standard & $\mathrm{Na}_{2} \mathrm{O}$ & MgO & $\mathrm{Al}_{2} \mathrm{O}_{3}$ & $\mathrm{SiO}_{2}$ & $\mathrm{~K}_{2} \mathrm{O}$ & $\mathrm{CaO}$ & $\mathrm{TiO}_{2}$ & MnO & FeOt & Total \\
\hline GOR132-G & 0.87 & 21.95 & 10.92 & 45.39 & 0.05 & 8.31 & 0.32 & 0.17 & 10.35 & 98.35 \\
\hline GOR132-G & 0.73 & 21.91 & 10.78 & 44.70 & 0.02 & 8.37 & 0.29 & 0.12 & 10.12 & 97.03 \\
\hline GOR132-G & 0.79 & 21.85 & 11.00 & 45.05 & 0.04 & 8.47 & 0.28 & 0.16 & 10.36 & 98.01 \\
\hline GOR132-G & 0.65 & 22.39 & 10.90 & 45.91 & 0.02 & 8.35 & 0.26 & 0.17 & 10.27 & 98.91 \\
\hline GOR132-G & 0.66 & 22.10 & 11.12 & 45.57 & 0.05 & 8.44 & 0.33 & 0.22 & 10.17 & 98.65 \\
\hline GOR132-G & 1.03 & 22.40 & 10.71 & 45.14 & 0.04 & 8.63 & 0.31 & 0.15 & 10.15 & 98.56 \\
\hline Mean & 0.79 & 22.10 & 10.91 & 45.29 & 0.04 & 8.43 & 0.30 & 0.17 & 10.24 & \\
\hline $1 \sigma$ & 0.13 & 0.22 & 0.14 & 0.39 & 0.01 & 0.11 & 0.02 & 0.03 & 0.10 & \\
\hline ML3B-G & 2.29 & 6.44 & 13.78 & 52.01 & 0.39 & 10.55 & 2.06 & 0.15 & 10.93 & 98.60 \\
\hline ML3B-G & 2.28 & 6.69 & 13.77 & 52.37 & 0.41 & 10.64 & 2.25 & 0.14 & 11.05 & 99.61 \\
\hline ML3B-G & 2.34 & 6.57 & 14.16 & 51.50 & 0.38 & 10.70 & 2.17 & 0.21 & 10.97 & 98.99 \\
\hline ML3B-G & 2.25 & 6.59 & 14.05 & 52.02 & 0.37 & 10.61 & 2.18 & 0.19 & 11.23 & 99.50 \\
\hline ML3B-G & 2.41 & 6.54 & 13.82 & 51.69 & 0.42 & 10.48 & 2.19 & 0.20 & 10.61 & 98.37 \\
\hline ML3B-G & 2.50 & 6.57 & 13.84 & 51.64 & 0.42 & 10.48 & 2.18 & 0.24 & 10.73 & 98.60 \\
\hline ML3B-G & 2.22 & 6.58 & 13.78 & 51.54 & 0.36 & 10.54 & 2.22 & 0.22 & 11.05 & 98.52 \\
\hline Mean & 2.33 & 6.57 & 13.89 & 51.83 & 0.39 & 10.57 & 2.18 & 0.19 & 10.94 & \\
\hline $1 \sigma$ & 0.09 & 0.07 & 0.14 & 0.30 & 0.02 & 0.08 & 0.05 & 0.03 & 0.19 & \\
\hline StHs6/80-G & 4.61 & 1.95 & 17.50 & 63.15 & 1.37 & 5.22 & 0.71 & 0.15 & 4.32 & 98.97 \\
\hline StHs6/80-G & 4.56 & 1.91 & 17.77 & 63.10 & 1.31 & 5.31 & 0.67 & 0.07 & 4.03 & 98.74 \\
\hline StHs6/80-G & 4.85 & 1.85 & 17.45 & 63.16 & 1.31 & 5.14 & 0.76 & 0.01 & 4.57 & 99.11 \\
\hline StHs6/80-G & 4.53 & 1.99 & 17.60 & 63.14 & 1.33 & 5.36 & 0.68 & 0.09 & 4.43 & 99.16 \\
\hline StHs6/80-G & 4.44 & 1.98 & 17.37 & 63.55 & 1.39 & 5.46 & 0.73 & 0.11 & 4.54 & 99.58 \\
\hline StHs6/80-G & 4.82 & 1.84 & 17.72 & 63.92 & 1.32 & 5.41 & 0.69 & 0.10 & 4.32 & 100.16 \\
\hline Mean & 4.64 & 1.92 & 17.57 & 63.34 & 1.34 & 5.32 & 0.71 & 0.09 & 4.37 & \\
\hline $1 \sigma$ & 0.15 & 0.06 & 0.14 & 0.30 & 0.03 & 0.11 & 0.03 & 0.04 & 0.18 & \\
\hline
\end{tabular}

B.

\begin{tabular}{|c|c|c|c|c|c|c|c|c|c|c|c|c|}
\hline Standard & $\mathbf{B a t c h}$ & $\mathbf{S i O}_{\mathbf{2}}$ & $\mathbf{T i O}_{\mathbf{2}}$ & $\mathbf{A l}_{\mathbf{2}} \mathbf{O}_{\mathbf{3}}$ & $\mathbf{F e O}$ & $\mathbf{M n O}$ & $\mathbf{M g O}$ & $\mathbf{C a O}$ & $\mathbf{N a}_{\mathbf{2}} \mathbf{O}$ & $\mathbf{K}_{\mathbf{2}} \mathbf{O}$ & $\mathbf{P}_{\mathbf{2}} \mathbf{O}_{\mathbf{6}}$ & $\mathbf{T o t a l}$ \\
\hline Lipari & 1 & 74.31 & 0.075 & 12.94 & 1.491 & 0.067 & 0.039 & 0.718 & 3.851 & 5.21 & 0.002 & 98.703 \\
\hline Lipari & $\mathbf{2}$ & 75.087 & 0.075 & 13.167 & 1.427 & 0.076 & 0.039 & 0.703 & 3.896 & 5.24 & 0.008 & 99.72 \\
\hline Lipari & 3 & 75.043 & 0.048 & 13.431 & 1.649 & 0.07 & 0.042 & 0.714 & 4.054 & 5.252 & 0.004 & 100.31 \\
\hline Lipari & 4 & 74.644 & 0.079 & 12.807 & 1.434 & 0.067 & 0.063 & 0.806 & 3.848 & 5.197 & 0.005 & 98.95 \\
\hline Lipari & 5 & 75.266 & 0.078 & 12.901 & 1.496 & 0.068 & 0.034 & 0.769 & 3.899 & 5.267 & 0.005 & 99.783 \\
\hline Lipari & 6 & 75.293 & 0.075 & 12.536 & 1.471 & 0.066 & 0.056 & 0.812 & 3.734 & 5.257 & 0.011 & 99.311 \\
\hline Lipari & $\mathbf{7}$ & 74.228 & 0.076 & 12.574 & 1.401 & 0.061 & 0.054 & 0.788 & 3.55 & 5.184 & 0.012 & 97.928 \\
\hline Lipari & $\mathbf{8}$ & 74.548 & 0.084 & 12.781 & 1.592 & 0.062 & 0.049 & 0.77 & 3.761 & 5.025 & 0.005 & 98.677 \\
\hline Lipari & $\mathbf{9}$ & 74.348 & 0.068 & 12.466 & 1.64 & 0.06 & 0.058 & 0.785 & 3.92 & 5.332 & 0.06 & 98.737 \\
\hline Lipari & $\mathbf{1 9}$ & 75.005 & 0.075 & 13.236 & 1.599 & 0.07 & 0.046 & 0.779 & 4.217 & 5.201 & 0.012 & 100.24 \\
\hline & $\mathbf{M e a n}$ & $\mathbf{7 4 . 7 7 7}$ & $\mathbf{0 . 0 7 3}$ & $\mathbf{1 2 . 8 7 8}$ & $\mathbf{1 . 5 2 3}$ & $\mathbf{0 . 0 6 7}$ & $\mathbf{0 . 0 4 9}$ & $\mathbf{0 . 7 7 0}$ & $\mathbf{3 . 8 7 5}$ & $\mathbf{5 . 2 1 7}$ & $\mathbf{0 . 0 1 4}$ & $\mathbf{9 9 . 2 9 4}$ \\
\hline & $\mathbf{1 0}$ & $\mathbf{0 . 4 8}$ & $\mathbf{0 . 0 1 0}$ & $\mathbf{0 . 3 1 9}$ & $\mathbf{0 . 0 9 2}$ & $\mathbf{0 . 0 0 5}$ & $\mathbf{0 . 0 1 0}$ & $\mathbf{0 . 0 3 9}$ & $\mathbf{0 . 1 8 0}$ & $\mathbf{0 . 0 8 0}$ & $\mathbf{0 . 0 1 7}$ & $\mathbf{0 . 7 7 0}$ \\
\hline
\end{tabular}

Table 1. Data obtained from MPI-DING (A) and Lipari obsidian (B) international glass standards used to calibrate the geochemical measurements reported in Table 3. 
with wavelength dispersive spectroscopy (EPMA WDS) conducted at the Tephra Analytical Unit, University of Edinburgh using a Cameca SX100 spectroscope with a 5 or $3 \mu \mathrm{m}$ beam diameter, an important prerequisite for analysing small cryptotephra shards (Hayward, 2011; Hall and Hayward, 2014). Secondary standards were operated throughout to check for analytical consistency, the results provided in Table 1.

\section{Results}

\subsection{Lithological description}

The main lithological units represented in the core sequence are illustrated in Figure 3, with depths defined by the core depth ( $\mathrm{cm}$ ) and also by altitude (m OD). Descriptions of the key characteristics of the main lithofacies units are summarized in Table 2 by core depth. Three major lithological units are recognised, the lower two consisting of mainly minerogenic deposits, which include distinctly laminated beds, while unit 3 has a relatively high organic content. Units 1 and 2 are described in the greatest detail, as they are the more complex and are considered to reflect key sedimentological changes within the basin.

\subsection{Interpretation of the lithological sequence}

Unit 1 most likely represents sedimentation within a glaciolacustrine context. The unit as a whole is dominated by minerogenic sediments with low organic carbon content and high magnetic susceptibility values, characterised by sorted sediments in Units $1 \mathrm{a}$ and $1 \mathrm{~b}$, and succeeded by unit 1c, in which sorted sediments appear to be initially distorted and then mixed to become a diamicton. The presence of outsized grains and clasts within 1c may suggest some sediment transport by ice-rafted debris. Unit $1 a$ is probably the result of a single event depositing massive, well-sorted sand into the basin, possibly as a high concentration sediment underflow. Due to the lack of other core sequences from the Turret basin with which to compare, it is not possible to gauge how proximal to source these sediments may have been deposited, but it is assumed that this sorted sediment was transported into the basin from the north west (i.e. from up-valley). Whether this was the first depositional event to accumulate at the time is difficult to establish, as the coring and percussion equipment used could not penetrate through more resistant sediment that underlies unit 1 . Unit $1 b$ is interpreted as distal glaciolacustrine varved sediment, with clear input of coarser sediment (silt) during the summer melt period and clay laminations deposited during the winter seasons. The sharp contacts separating both silt-to-clay and clay-to-silt layers indicate sudden switches between sediments delivered to the deposition point by current flow and finer material settling downwards from suspension (see Palmer et al., 2010). The thickness of the individual varved layers at Turret Bank $(8-15 \mathrm{~mm})$ is similar 


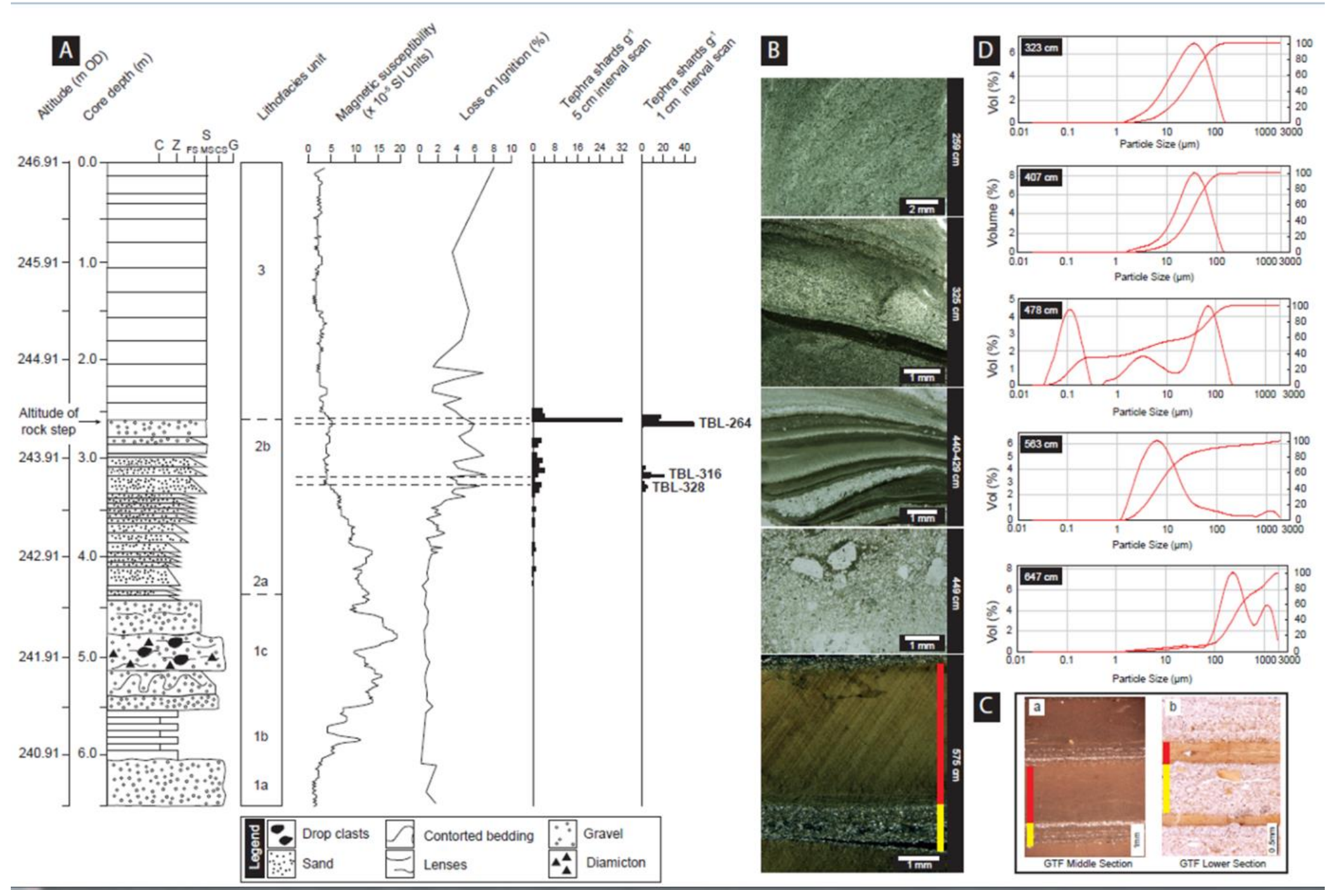

Figure 3. A. Lithofacies units for the Turret Bank core, including down-core variations in loss-on-ignition (\%), magnetic susceptibility $\left(\mathrm{x} 10^{-5} \mathrm{SI}\right.$ Units) and tephra shard distributions for $5 \mathrm{~cm}$ interval rangefinder samples and $1 \mathrm{~cm}$ interval sampling. B. Photomicrographs (note scale bars) of example sedimentary structures associated with lithofacies units $1 \mathrm{~b}$ to $2 \mathrm{~b}$ (Table 2) in plane-polarised light except for the cross-polarised light image of unit $1 \mathrm{~b}(575 \mathrm{~cm})$. C. Two cross-polarised light photomicrographs of varves from the Glen Turret Fan (GTF) sequence: a) is from the upper part of the GTF section, where the overall thickness of the varves is $>3 \mathrm{~mm}$, with winter clay layers (red bar) thicker than summer silt layers (yellow bar); b) is from the lower GTF section which has thinner varves $(0.5-1.5 \mathrm{~mm})$ with summer layers thicker than winter ones. These characteristics show clear similarity with the varves identified in the Turret Bank sequence (see text for further details). D. Representative frequency and cumulative
particle
size
data
for the
units
defined
in
Table
and
described
in
the
text. 


\begin{tabular}{|c|c|c|c|}
\hline Unit & Sub-unit & $\begin{array}{c}\text { Core } \\
\text { Depth }(\mathrm{cm})\end{array}$ & Description \\
\hline 3 & & $267-0$ & $\begin{array}{l}\text { Banded organic silts and very fine sands where the organic } \\
\text { content (LOI percentages) increases to greater than } 5-9 \% \text {. } \\
\text { Magnetic susceptibility values of between } 0-5 \text {. Banding } \\
\text { within this unit marked by concentrations of minerogenic } \\
\text { material and relatively lower organic content. }\end{array}$ \\
\hline \multirow[b]{2}{*}{2} & $2 b$ & $415-267$ & $\begin{array}{l}\text { Thicker laminations ( }>5 \mathrm{~mm} \text { ) composed of both massive fine } \\
\text { sand and very fine sand, grading to coarse or medium silt } \\
\text { and normally consolidated. Laminations have sharp upper } \\
\text { contacts but in places, particularly towards the top of the } \\
\text { unit, these are replaced by thin beds of massive fine sand. } \\
\text { The latter contain very fine fragments of organic material that } \\
\text { become more common toward the top of the sub-unit. LOI } \\
\text { varies between } 4-6 \% \text { and magnetic susceptibility values are } \\
4-5 \text {. }\end{array}$ \\
\hline & $2 a$ & $447-415$ & $\begin{array}{l}\text { Laminated, normally consolidated silts and sands, the } \\
\text { majority between } 1-5 \mathrm{~mm} \text { thickness but occasionally up to } \\
20 \mathrm{~mm} \text { thick. At the microscale they grade from very fine } \\
\text { sand to medium silt, but occasionally the medium silt grades } \\
\text { into very fine silt and clay with a sharp upper contact. A } \\
\text { masepic fabric is present in the finer components of the } \\
\text { laminations. There is no distinct boundary between subunits } \\
2 \mathrm{a} \text { and } 2 \mathrm{~b} \text {. LOI is } \sim 2 \% \text { and magnetic susceptibility is } \\
\text { persistently between } 10-15 \text {, gradually decreasing through } \\
\text { the graded contact to subunit } 2 \mathrm{~b} \text {. }\end{array}$ \\
\hline \multirow[t]{3}{*}{1} & $1 \mathrm{c}$ & $556-447$ & $\begin{array}{l}\text { Predominantly unsorted, normally consolidated sediment } \\
\text { with a clay- rich matrix (see particle size data for } 478 \mathrm{~cm} \text { ) } \\
\text { and large oversized clasts (up to } 20 \mathrm{~mm} \text { b-axis). Some } \\
\text { evidence of lamination but these have been heavily } \\
\text { deformed and draped over larger clasts. Micro-scale } \\
\text { analysis reveals clear discontinuous laminations with } \\
\text { alternation between coarse sand layers and beds containing } \\
\text { clay intraclasts and anomalously sized grains, with finer } \\
\text { laminae composed of medium silt. (see Fig } 3 \\
\text { photomicrograph). A more sorted medium sand unit of } \sim 20 \\
\mathrm{~cm} \text { thickness near the base of the subunit grades into the } \\
\text { unsorted sediment above. LOI values are the lowest in the } \\
\text { core (1-2\%) while magnetic susceptibility values are at their } \\
\text { highest }(15-20) \text {. Contact with the overlying unit is sharp and } \\
\text { non-erosive. }\end{array}$ \\
\hline & $1 b$ & $602-556$ & $\begin{array}{l}\text { Well defined couplets of silt and clay laminations, the former } \\
\text { normally between } 0.75-2.5 \mathrm{~mm} \text { in thickness and contain } \\
\text { coarse and medium silt, while the latter are thicker (3.5-10 } \\
\mathrm{mm} \text { ) and grade from very fine silt to clay with a masepic } \\
\text { plasmic fabric. Contacts between laminations are sharp. The } \\
\text { laminations become increasingly distorted towards the top of } \\
\text { the subunit. LOI is low }(1-2 \%) \text {. Magnetic susceptibility is } \\
\text { generally between } 5 \text { and } 10 \text {, but a single peak reaches } 15 \text {. }\end{array}$ \\
\hline & $1 a$ & $650-602$ & $\begin{array}{l}\text { Massive, well sorted medium to coarse sand, with higher silt } \\
\text { content towards top. Contact with subunit } 1 \mathrm{~b} \text { is sharp and } \\
\text { non-erosive. LOI values are around } 2-3 \% \text { and magnetic } \\
\text { susceptibility values are between } 0 \text { and } 3 \text {. }\end{array}$ \\
\hline
\end{tabular}

Table 2. Summary of the lithological variations observed in the sequence recovered from Core $A$, Turret Bank, and the main lithostratigraphic units and sub-units identified. Depths are relative to the site datum with $0 \mathrm{~cm}$ at $246.91 \mathrm{~m}$ OD. 
to the middle and upper sections of the varved sediments observed on the distal edge of the Glen Turret Fan. Deformation of the upper layers in this sub-unit might have been caused by the emplacement of unit $1 \mathrm{c}$ or alternatively by the coring procedure, since they only occur at the top of a core length, where the core barrel makes maximum impact on the sediment being penetrated. Unit 1c, which comprises massive clay with a few pebbles and granules, contains two sand beds and becomes coarser with medium sand toward the top, which is also indicative of glaciolacustrine sedimentation. The remnants of some laminated structures indicate that pulses of sediment entered the basin with relatively high concentrations of icerafted debris forming dropstones. There are also fractures within the clay material suggesting erosion/compression of previously- deposited laminated layers.

Unit 2a represents deposition in a lacustrine system, based on the nature of the sediment structures, low organic carbon content and high magnetic susceptibility values. Graded, finely laminated minerogenic sediments suggest relatively low energy sediment flows into the lake. There was sufficient time between flows to enable sediment to fall from suspension, including occasional clay layers, which may have coincided with periodic freezing of the lake waters. However, this is not a persistent characteristic of the sediments in this sub-unit and therefore it is uncertain whether these represent annually-deposited layers. Through the graded transition to Unit $2 b$, the deposits contain slightly coarser sediments (very fine sand grading to medium silt) and the laminations become thicker and more massive, which suggests that the basin was infilling more rapidly with sediment, causing the lake to shallow. The higher organic content of some of the layers suggests in-washing of organic materials from the catchment, perhaps reflecting an increasing biomass on adjacent catchment slopes or within the lake itself.

Unit 3 is considered a floodplain deposit where rhythmic inputs of coarser minerogenic material were delivered intermittently during periods of flood, while at other times vegetation was able to colonise and stabilise the floodplain. This generates banding in the upper unit, with alternations between organic material and massive minerogenic sediments, which contrasts with the underlying unit 2. Crucially, the transition observed between units 2 and 3 occurs precisely at an altitude of $244.44 \mathrm{~m} \mathrm{OD}$, the same height as the rock step identified in the Turret gorge, referred to in section 2 , and probably reflects the transition from a lacustrine system to that of fluvial system (see section 6).

\subsection{Pollen stratigraphy}

The sequence was sampled at $16 \mathrm{~cm}$ intervals between 64 and $500 \mathrm{~cm}$ depth and the samples prepared using the procedures outlined in section 4 . Pollen content was relatively 
high between 64 and $328 \mathrm{~cm}$, so that the majority of samples could be counted to 300 TLP (total land pollen). Below this, pollen content was significantly lower and counts were therefore restricted to 200 TLP, with one sample $(368 \mathrm{~cm})$ counted to 150 TLP only. Below $400 \mathrm{~cm}$, the sediments are effectively non-polleniferous. Figure 4, compiled using C2 software (Juggins, 2007), presents relative percentage variations for the main terrestrial pollen taxa in the dataset, and includes some of the key indicator taxa on which Scottish Lateglacial and early Holocene pollen zones are commonly defined. The diagram is divided into six local pollen assemblage zones (lpaz), the key characteristics for which are summarised in Table 3.

\subsection{Interpretation of the pollen data}

Figure 4 reveals an orderly sequence from the base of pollen spectra dominated successively by Salix-Rumex, Empetrum, Juniperus, Betula and Corylus, a sequence that is typical of early Holocene deposits in Scotland (e.g. Lowe and Walker, 1979, 1986; Walker and Lowe, 1981, 1982; Dawson et al., 1987; Benn et al., 1992), including sites within and adjacent to Glen Roy (Lowe and Cairns, 1991; Kelly et al., 2017). The pollen sequence is in general comparable to that published by Lowe and Cairns (1991) except in two important respects: (i) there are no contaminant pollen (Betula, Alnus, Corylus) in the lower part of the profile (zone TBpaz-1), which is dominated by herbaceous taxa; and (ii) Juniperus is much more clearly represented as a distinct peak (zone TBpaz-3) that succeeds the Empetrum phase (zone TBpaz-2/3); this resembles more clearly the pattern shown in other Scottish early Holocene records. The pollen data therefore indicate that the sediment sequence between 400 and $220 \mathrm{~cm}$ from the Turret Bank basin accumulated during the early Holocene, and sediments lower in the core sequence are non-polleniferous. Further implications of these data are considered in section 6 .

\subsection{Tephrostratigraphy}

Contiguous $5 \mathrm{~cm}$-thick samples were extracted from the core sequence between 250 and $450 \mathrm{~cm}$ depth relative to the site datum (242.41 to $244.41 \mathrm{~m} \mathrm{OD}$ ) and examined for tephra content using the preparation procedures outlined in section 4 . This interval spans the early Holocene pollen sequence, between the lowest polleniferous level in the sequence and the onset of the Betula rise (Figure 4). Although the number of tephra shards recovered were generally low, the 5-cm data suggested a peak in shard concentration at $\sim 260-264 \mathrm{~cm}$ depth, and a cluster of smaller peaks between $\sim 280$ and $340 \mathrm{~cm}$, while a 'tail' of very low shard counts extends to $\sim 430 \mathrm{~cm}$ depth (Figure 3). Contiguous samples of $1 \mathrm{~cm}$ thickness were extracted from the core between 260 and $265 \mathrm{~cm}$ and between 310 and $330 \mathrm{~cm}$ depth, to refine glass shard distributions in these intervals. These data revealed a prominent peak 


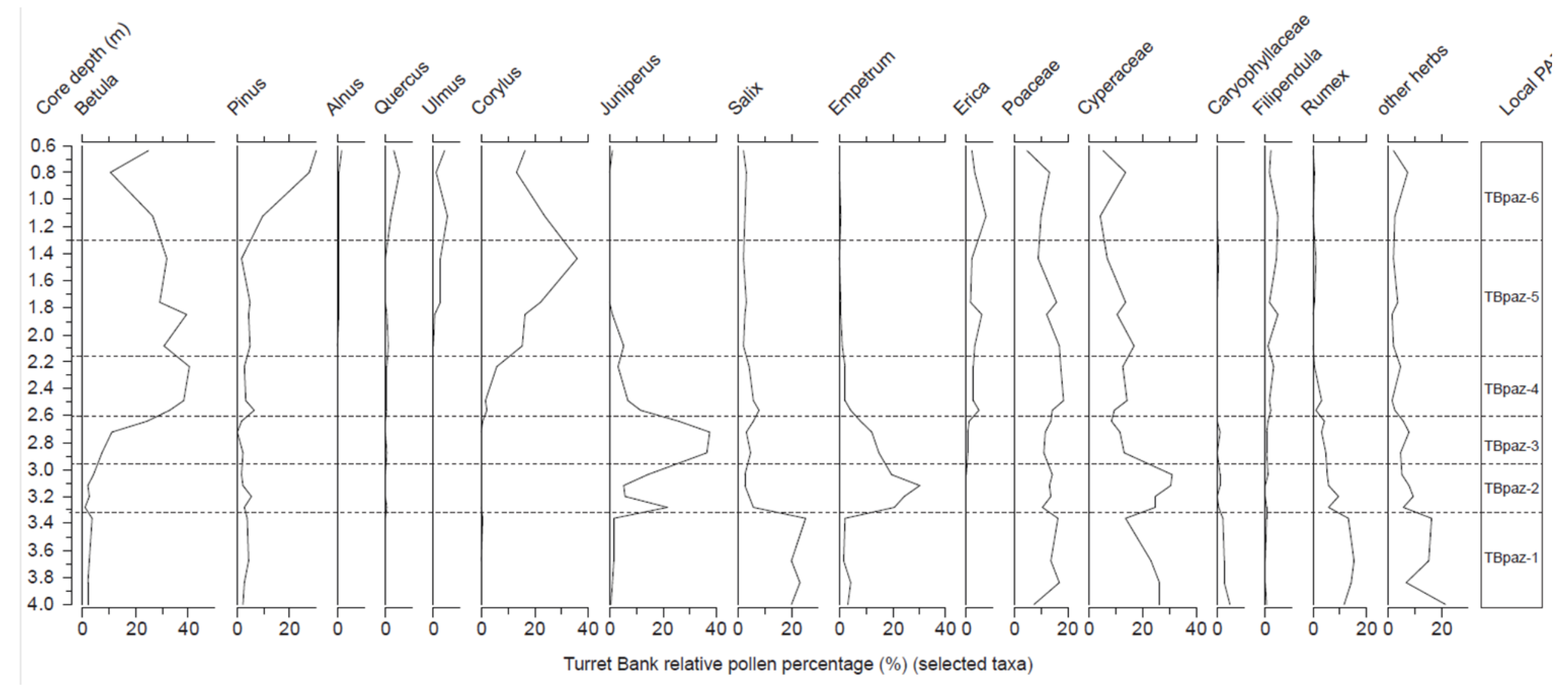

Figure 4. Relative pollen diagram (scales below curves are percentage of total land pollen) for Core A of the Turret Bank sediment sequence, showing main taxa only. The key characteristics of the local pollen assemblage zones (Ipaz) are summarised in Table 3. 


\begin{tabular}{|c|c|l|}
\hline LPAZ & Depth $(\mathrm{cm})$ & \multicolumn{1}{|c|}{ Key pollen indicators } \\
\hline TBpaz-6 & $143-60$ & $\begin{array}{l}\text { A rise in Pinus pollen (to }>20 \% \text { TLP) with a concomitant reduction in } \\
\text { percentages of Betula and Corylus. }\end{array}$ \\
\hline TBpaz-5 & $223-143$ & $\begin{array}{l}\text { A rise in Corylus percentage (to in excess of 30\% TLP), while birch } \\
\text { percentages are maintained at relatively high levels. Empetrum has } \\
\text { declined almost to zero. }\end{array}$ \\
\hline TBpaz-4 & $270-223$ & $\begin{array}{l}\text { Betula rises to 40\% TLP, while Juniperus pollen decline markedly and } \\
\text { Empetrum values continue to decline, as do herbaceous taxa. }\end{array}$ \\
\hline TBpaz-3 & $310-270$ & $\begin{array}{l}\text { A pronounced rise in Juniperus pollen (to 30\% TLP) accompanies a } \\
\text { significant decline in Empetrum pollen and continued reductions in } \\
\text { herbaceous taxa. }\end{array}$ \\
\hline TBpaz-2 & $340-310$ & $\begin{array}{l}\text { Significant drops in percentages of Salix, Rumex and other } \\
\text { herbaceous taxa, but especially noteworthy is a marked rise in } \\
\text { Empetrum pollen (to 30\% TLP); there is an initial rise in Juniperus } \\
\text { pollen but this is not sustained. }\end{array}$ \\
\hline TBpaz-1 & $400-340$ & $\begin{array}{l}\text { Pollen content is low: the pollen spectra are dominated by Salix and } \\
\text { Rumex, with other herbaceous taxa and Huperzia selago also } \\
\text { important. Trees and shrubs are at their lowest levels in the diagram. }\end{array}$ \\
\hline
\end{tabular}

Table 3. Key characteristics of the pollen-stratigraphic sequence shown in Figure 4. LPAZ - local pollen assemblage zone; TB - Turret Bank; depths are relative to the site datum (246.91 m OD).

(50 shards $\mathrm{g}^{-1}$ ) at $264 \mathrm{~cm}$, hereafter referred to as TBL-264. Two smaller but nevertheless discrete peaks are evident at 316 and $328 \mathrm{~cm}$ depth (TBL-316, TBL-328), with the former the more prominent, revealing a shard concentration of 21 shards $\mathrm{g}^{-1}$ when examined at $1-\mathrm{cm}$ resolution. The shards from all levels were of variable shape, including elongate, irregular or equant types, but generally contained few vesicles. Some shards, however, showed evidence of hydration rims, especially those from TBL-316 and TBL-328, though these were not selected for chemical analysis. Geochemical measurements were obtained from 27 glass shards (Table 4) and the results compared with published analytical data reported in the sources listed in the caption for Figure 5.

\subsection{Interpretation of the tephra data}

The geochemical data indicate that all the measured samples are rhyolitic in composition (Figure 5a) but can clearly be differentiated on relative proportions of major elements (Figure 5b), $\mathrm{FeO}$ v. $\mathrm{CaO}$ (Figure 5c) and $\mathrm{TiO}_{2} \mathrm{v} \mathrm{Al}_{2} \mathrm{O}_{3}$ (Figure 5d). The data for the younger tephra peak (254-264 cm, Figure 5) consistently plot within the chemical envelopes for the Askja-S Tephra, which has been detected in sites in Sweden (Davies et al., 2003; Lilja et al., 2013), Norway (Pilcher et al., 2005), Ireland (Turney et al., 2006), the Faroe Islands (Lind and Wastegård, 2011), Germany (Lane et al., 2012a) and Switzerland (Lane et al., 2011), and more recently at a site in the Spean valley, only $\sim 13 \mathrm{~km}$ due south of the Turret Bank site (Kelly et al., 2017). The current best-estimate age for the Askja-S Tephra, with a $2 \sigma$ error range, is 10,944-10,716 cal BP (Bronk Ramsey et al., 2015). 

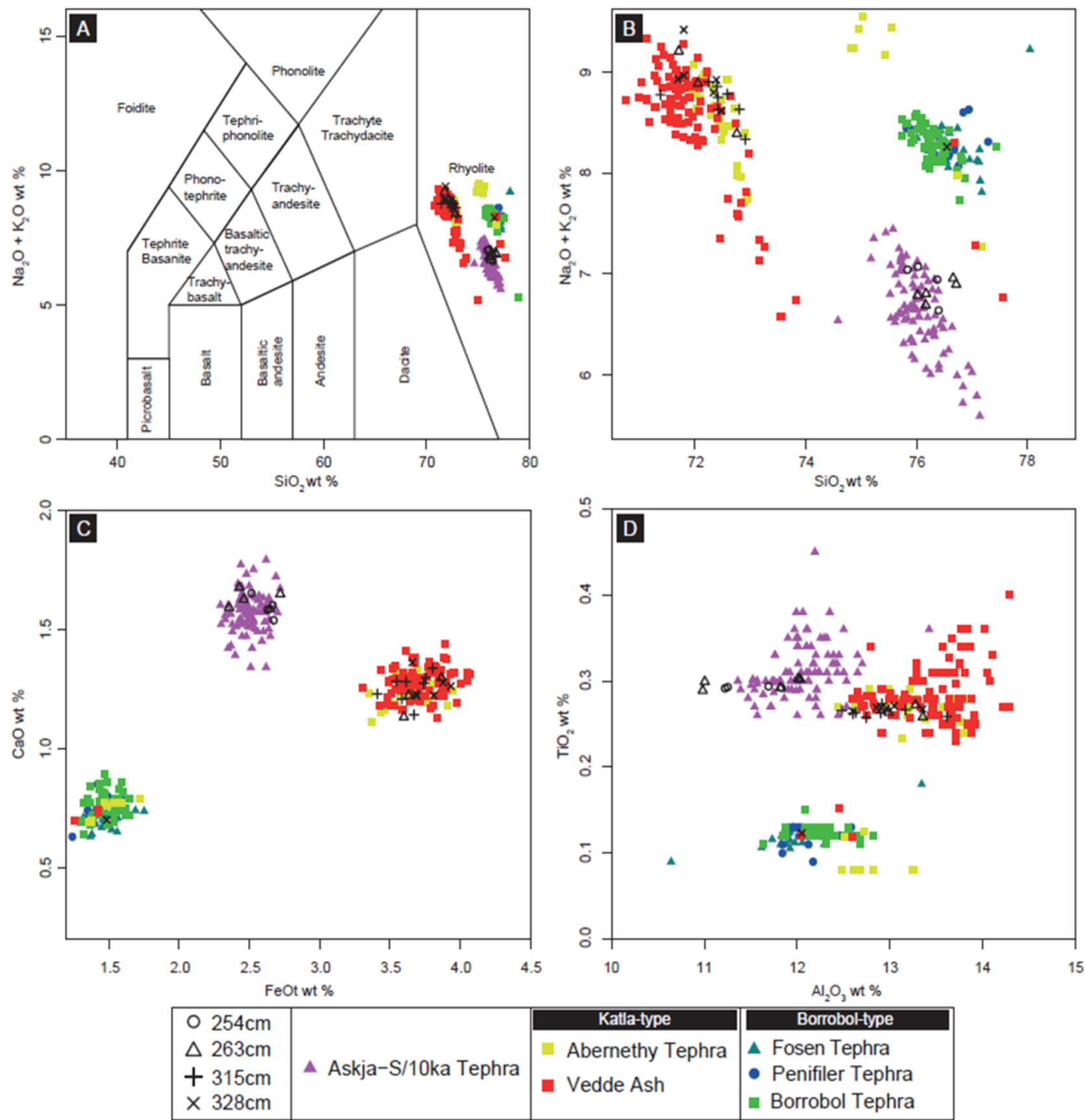

Abernethy Tephra $\Delta$ Fosen Tephra

Vedde Ash

- Penifiler Tephra

- Borrobol Tephra

Figure 5. Plots comparing the geochemical measurements obtained from the data listed in Table 4 with the chemical envelopes for close-matching Lateglacial and early Holocene tephras: (A) total alkali v. silica (TAS plot); (B) expansion of the data shown in $\mathrm{A}$; (C) $\mathrm{CaO}$ v. $\mathrm{FeO}$ data; (D) $\mathrm{TiO}_{2} \mathrm{v}$. $\mathrm{Al}_{2} \mathrm{O}_{3}$ data. The chemical envelopes are based on the following sources: Borrobol type - Lind et al., 2013, 2016; Timms et al., 2016; Askja-S - Davies et al., 2003; Pilcher et al., 2005; Turney et al., 2006; Lind and Wastegård 2011; Lane et al., 2013; Wulf et al., 2016; Kelly et al., 2017; Timms et al., 2016; Abernethy Tephra - Matthews et al., 2011; MacLeod et al. 2015; Vedde Ash - Matthews et al., 2011; Lane et al., 2012b; MacLeod et al., 2015; Timms et al., 2016. 


\begin{tabular}{|c|c|c|c|c|c|c|c|c|c|c|}
\hline $\begin{array}{c}\text { Sample } \\
\text { depth }(\mathrm{cm})\end{array}$ & $\mathrm{SiO}_{2}$ & $\mathrm{TiO}_{2}$ & $\mathrm{Al}_{2} \mathrm{O}_{3}$ & $\mathrm{FeO}$ & $\mathrm{MnO}$ & $\mathrm{MgO}$ & $\mathrm{CaO}$ & $\mathrm{Na}_{2} \mathrm{O}$ & $\mathrm{K}_{2} \mathrm{O}$ & Total \\
\hline 264 & 75.167 & 0.303 & 12.011 & 2.720 & 0.092 & 0.234 & 1.647 & 4.175 & 2.539 & 98.923 \\
\hline 264 & 75.068 & 0.302 & 12.033 & 2.430 & 0.083 & 0.259 & 1.674 & 4.123 & 2.584 & 98.597 \\
\hline 264 & 73.733 & 0.292 & 11.817 & 2.648 & 0.085 & 0.173 & 1.583 & 3.971 & 2.507 & 96.851 \\
\hline 264 & 71.024 & 0.258 & 13.353 & 3.636 & 0.139 & 0.183 & 1.223 & 5.008 & 3.751 & 98.615 \\
\hline 264 & 70.526 & 0.264 & 12.985 & 3.601 & 0.148 & 0.150 & 1.131 & 4.807 & 3.325 & 96.985 \\
\hline 264 & 71.437 & 0.272 & 13.273 & 3.868 & 0.143 & 0.163 & 1.295 & 5.512 & 3.659 & 99.665 \\
\hline 264 & 73.290 & 0.289 & 10.982 & 2.461 & 0.079 & 0.223 & 1.624 & 4.137 & 2.451 & 95.591 \\
\hline 264 & 72.892 & 0.299 & 11.004 & 2.357 & 0.091 & 0.237 & 1.590 & 4.172 & 2.445 & 95.137 \\
\hline 254 & 72.206 & 0.293 & 11.252 & 2.630 & 0.090 & 0.209 & 1.581 & 4.275 & 2.443 & 95.030 \\
\hline 254 & 72.941 & 0.294 & 11.690 & 2.516 & 0.087 & 0.231 & 1.650 & 4.242 & 2.532 & 96.228 \\
\hline 254 & 75.365 & 0.292 & 11.831 & 2.667 & 0.089 & 0.258 & 1.600 & 3.945 & 2.605 & 98.702 \\
\hline 254 & 73.271 & 0.292 & 11.221 & 2.674 & 0.089 & 0.193 & 1.537 & 4.153 & 2.510 & 95.987 \\
\hline 316 & 70.105 & 3.411 & 12.632 & 0.142 & 0.264 & 0.204 & 1.228 & 4.918 & 3.392 & 96.325 \\
\hline 316 & 71.372 & 3.758 & 12.913 & 0.135 & 0.274 & 0.195 & 1.297 & 5.002 & 3.620 & 98.602 \\
\hline 316 & 68.900 & 3.586 & 12.598 & 0.153 & 0.262 & 0.174 & 1.206 & 5.000 & 3.487 & 95.402 \\
\hline 316 & 69.689 & 3.673 & 12.480 & 0.133 & 0.266 & 0.202 & 1.141 & 5.005 & 3.426 & 96.057 \\
\hline 316 & 69.218 & 3.742 & 13.611 & 0.157 & 0.259 & 0.208 & 1.272 & 4.927 & 3.580 & 97.020 \\
\hline 316 & 70.401 & 3.616 & 12.743 & 0.152 & 0.258 & 0.184 & 1.280 & 5.185 & 3.425 & 97.277 \\
\hline 316 & 72.166 & 3.548 & 13.167 & 0.137 & 0.267 & 0.171 & 1.282 & 4.511 & 3.738 & 99.019 \\
\hline 316 & 71.316 & 3.805 & 12.899 & 0.152 & 0.263 & 0.215 & 1.336 & 4.860 & 3.633 & 98.515 \\
\hline 328 & 73.042 & 1.487 & 12.047 & 0.037 & 0.123 & 0.106 & 0.700 & 3.977 & 3.903 & 95.433 \\
\hline 328 & 69.680 & 3.661 & 13.043 & 0.142 & 0.271 & 0.195 & 1.361 & 5.281 & 3.418 & 97.090 \\
\hline 328 & 70.796 & 3.934 & 13.351 & 0.141 & 0.268 & 0.186 & 1.260 & 5.193 & 3.622 & 98.790 \\
\hline 328 & 70.337 & 3.880 & 12.600 & 0.139 & 0.265 & 0.194 & 1.276 & 4.864 & 3.498 & 97.092 \\
\hline 328 & 71.177 & 3.814 & 12.907 & 0.140 & 0.269 & 0.213 & 1.222 & 4.722 & 3.934 & 98.432 \\
\hline 328 & 70.929 & 3.687 & 12.853 & 0.127 & 0.269 & 0.157 & 1.229 & 5.151 & 3.591 & 98.028 \\
\hline 328 & 70.676 & 3.691 & 12.955 & 0.142 & 0.268 & 0.216 & 1.220 & 5.658 & 3.613 & 98.471 \\
\hline
\end{tabular}

Table 4. Major oxide concentrations (raw data) of volcanic glass shards recovered from the Turret Bank sediment sequence.

The geochemical data obtained from TBL-316 and TBL-328 are more difficult to interpret. With the exception of one sample, the data clearly fall within the chemical envelope for tephra sourced from Katla, Iceland, but several tephra layers detected in sites in Britain have this source in common, and hence have identical chemical signatures. These include the Vedde Ash, widespread in Europe and dated to the mid-Younger Dryas (Loch Lomond Stadial) (Lane et al., 2012b), the Abernethy Tephra, which is not well dated yet, but is consistently found close to the Stadial-Holocene lithostratigraphic boundary (MacLeod et al., 2015) and the Suðuroy Tephra; the last-named can be discounted as a possible correlative for TBL-316 or TBL-328, since it post-dates the Askja-S Tephra (Wastegård, 2002; Housley et al., 2012). However, it is difficult to discriminate between the other two possibilities, for insufficient chemical information is available to characterise the tephra deposits that extend 
between $\sim 280$ and $430 \mathrm{~cm}$ depth in the profile (Figure 3): the tephra concentrations throughout this interval are variable, but generally low, and they could represent several different ash depositional events, or the redeposition of tephra from a single source over an unknown period of time. This is an issue we return to in the next section. The exceptional sample alluded to above plots within the chemical envelopes for the Borrobol and Penifiler tephras, but since tephra layers with this chemical signature are found in both interstadial and early Holocene deposits (e.g. Davies et al., 2004; Pyne-O'Donnell et al., 2008; Lind et al., 2013; 2016), the significance of this single aberrant measurement remains enigmatic.

\section{Synthesis and discussion}

The lithostratigraphic evidence described in section 5.2 suggests that sedimentation at the Turret Bank site was initiated in three stages: first, the inception of a glaciolacustrine system, reflected in particular by clear glaciolacustrine varves; second, a rapidly infilling sequence, characterised by coarser laminated sediments, probably accumulating in a small lake basin that was impounded by the rock bar adjacent to Turret Fan (altitude of $244.44 \mathrm{~m} \mathrm{OD);} \mathrm{and}$ third, a fluvial/floodplain system that has been maintained to the present time. A chronology for this sequence of events can be inferred from the pollen- and tephrostratigraphical information presented above, and synthesised in Figure 6. An early Holocene age for the pollen sequence is supported by the identification of the Askja-S Tephra, dated to $\sim 10.83 \mathrm{ka}$ (Bronk Ramsey et al., 2015). This is consistent with the data reported from the nearby site of Inverlair (Kelly et al., 2017), where the Askja-S Tephra has also been identified: in both sequences this tephra layer coincides with the end of the prominent Juniperus phase (Figure 6). It is speculated that TBL-328, the most prominent tephra peak below the Askja-S, could represent the Abernethy Tephra. Although this cannot be confirmed on current evidence, two observations appear to support this option. First, TBL-328 coincides with the first distinct rise in LOI (Figure 3) and with the end of the early Holocene Rumex phase in the pollen diagram (Figure 4), consistent with the stratigraphic position of the Abernethy Tephra in other Scottish sequences (MacLeod et al., 2015). Second, the Abernethy Tephra has also been identified within the nearby varved sediment sequence that overlies the Glen Turret Fan (MacLeod et al., 2015) at an approximately similar stratigraphic position, although the first appearance of tephra in the Turret Bank sequence (at $430 \mathrm{~cm}$ ) may reflect reworking of glaciolacustrine sediments and of tephra shards into the shallow basin. On present evidence, therefore, the possibility that some or all of the Katla-type tephra between 420 and $\sim 300 \mathrm{~cm}$ in the Turret Bank sequence could instead reflect reworking from the Vedde Ash cannot be discounted. 


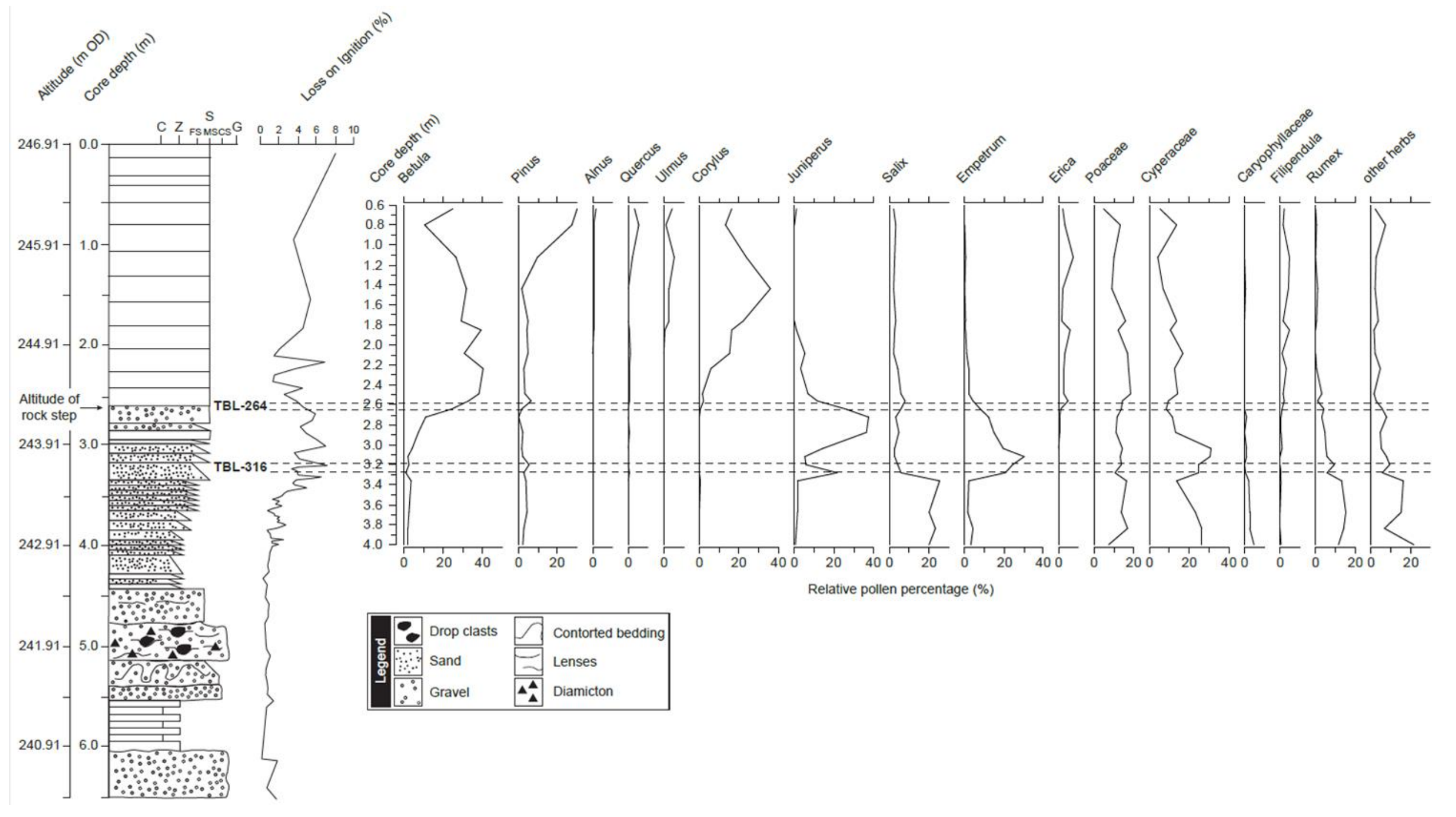

Figure 6. Synthesis of the litho-, pollen- and tephrostratigraphical evidence obtained from the Turret Bank sequence. 
The collective evidence presented here supports the interpretation of the Turret Bank sequence as having been deposited during the Stadial-Holocene transition. We find no evidence for deposits that pre-date the Stadial: this is also true for the entire catchment of Glen Roy and adjacent catchments, such as the Spean and Gloy valleys. For example, the basal lake sediments in an enclosed basin on the col between Glen Gloy and the Allt a' Chòmhlain valley, which drains to the Turret (Figure 1), also date to the early Holocene (Lowe and Cairns, 1991). Admittedly, however, the drilling of the Turret Bank sediment sequence reported here did not succeed in making contact with bedrock, gravels or a subglacial till, but terminated in a very stiff sand bed, and therefore the possibility that older deposits lie deeper in the sequence still cannot be discounted. Indeed, there is abundant evidence on neighbouring slopes for instability induced through paraglacial processes (Figure 7) and slip failures (Figure 6 in Sissons, 2017), and these, together with the products of periglacial activity, could have led to deposition of coarse debris in the Turret basin during the Loch Lomond Stadial, which may have buried older (Interstadial) sediments beneath. The conclusion, therefore, that the oldest sediments within the Turret basin are of Stadial age is still open to the criticism of resting on the 'absence of evidence'. But this is equally true of alternative proposals that rely on evidence of, for example, buried Interstadial soil horizons or pre-Stadial lake sediments, which are also absent. On the evidence that is available, therefore, we propose the following sequence of events (see Figure 8 ) to be reflected in the stratigraphical record (Table 2) recorded for the Turret Bank site:

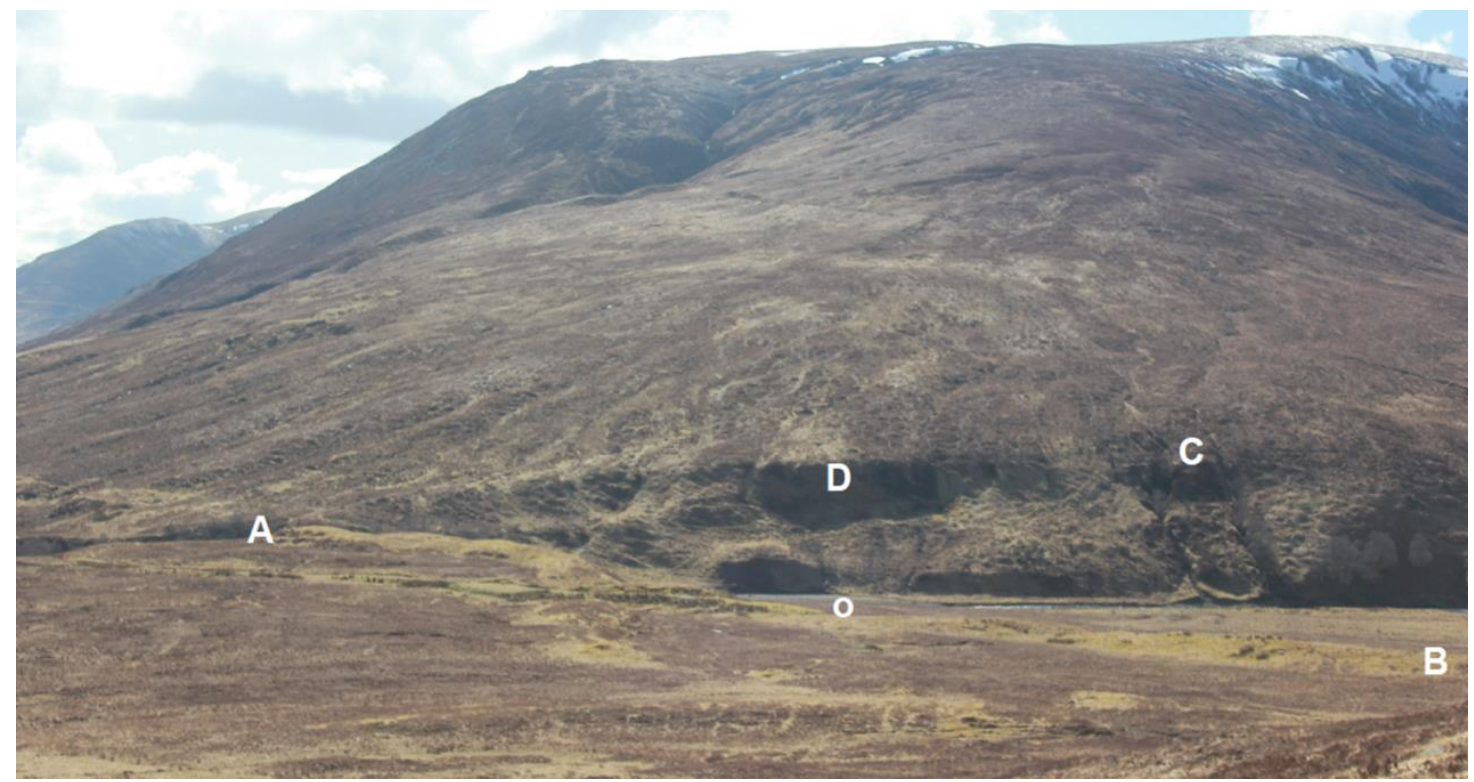

Figure 7. View taken from the $325 \mathrm{~m}$ shoreline near Allt Dearg (NN347928) across the westward limit of the Turret Fan (foreground). Linear ridges mark the margin of the fan (A-B), beyond which is the Turret floodplain, with the River Turret at the foot of the slope in the middle distance (small 'o' marks the floodplain surface, close to the Turret Bank site). The far flank of the Turret valley shows evidence of landslips (C) and landslip scars (D), which could have resulted from paraglacial relaxation following the retreat of a glacier, which terminated at this locality. 


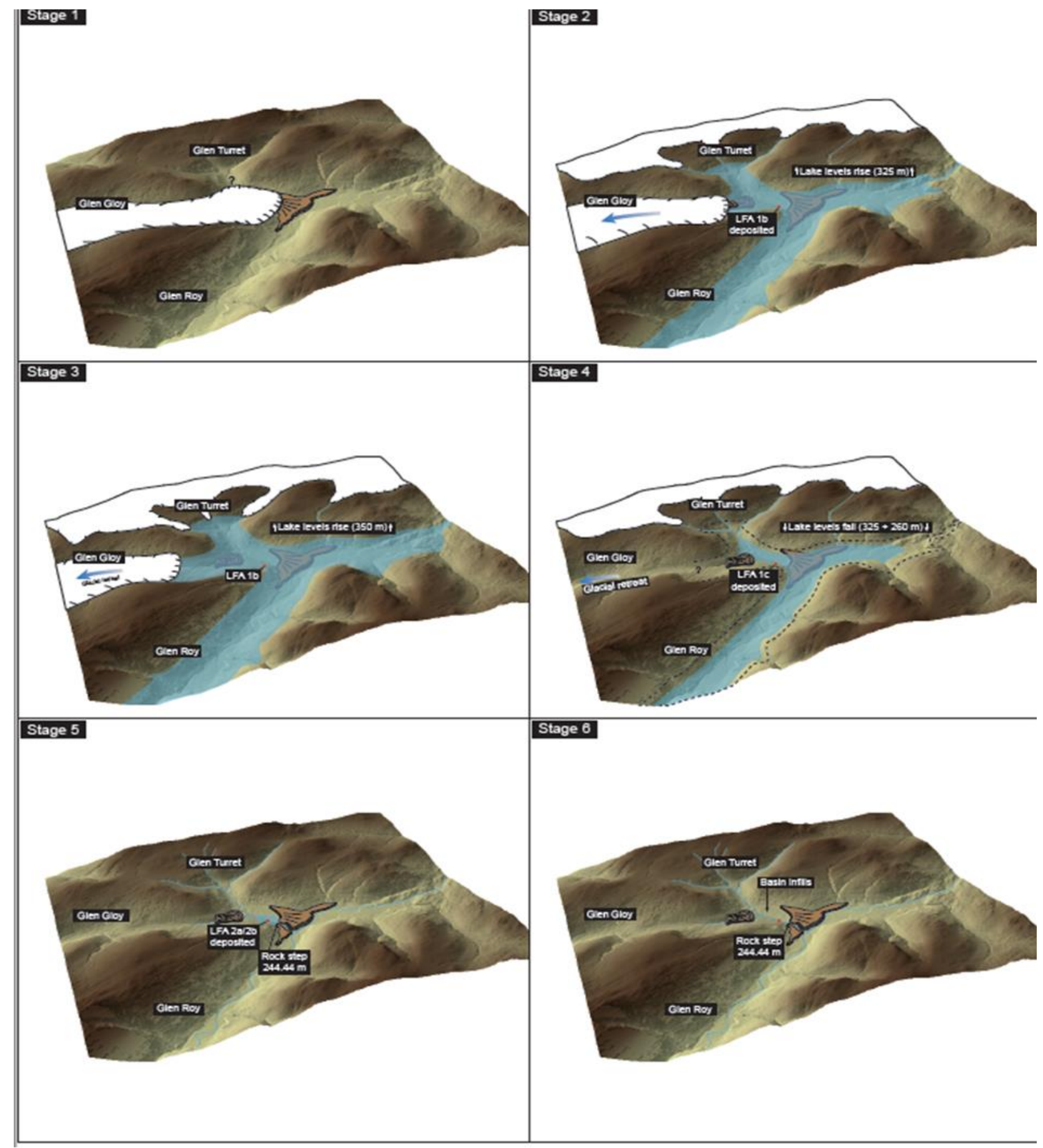

Figure 8. Schematic illustration of the sequence of events in the area of the Glen Turret-Glen Roy confluence during the Loch Lomond Stadial, based on the evidence presented in this paper. Note that the precise positions of the margins of the inferred glacial limits, and the exact timing of glacial advance and retreat, are not yet clear. The scheme is therefore approximate, serving to aid visualisation of the order of events considered to be reflected in the Turret Bank sedimentary sequence. The scheme incorporates some aspects of the evidence presented by Sissons (2017) and Cornish (2017) for the location of the Gloy-Turret glacier maximum and subsequent retreat stages (Stages 1 to 4), and by Boston et al. (2015) and Boston and Lukas (2017) for advance of ice into the upper Turret catchment from a plateau icefield that occupied the western valleys of the Monadhliath Mountains (Stages 2 and 3). In Stage 5 the main Roy lakes have drained and a small lake is impounded by the Turret Fan. Rapid incision leads to the cutting of the gully at the southern margin of the fan, down to the rock step at $244.44 \mathrm{~m}$ OD (Stage 5). The small lake subsequently infills with sediment, a process that was virtually complete by $10.83 \mathrm{ka}$ (the age of the Askja-S Tephra), leading to the formation of a flood-plain in the Turret valley (Stage 6). 


\section{Stage 1 (Figure 8-1)}

Glacier ice advances into the Turret Valley during the early part of the Loch Lomond Stadial, possibly from Glen Gloy, and terminates at the lateral moraine ridges at the western margin of the Turret fan. At this stage the ice that eventually invaded lower Glen Roy was either not yet sufficiently robust in Glen Spean to be able to dam the $260 \mathrm{~m}$ lake, allowing subaerial deposits to build up at the Turret glacier terminus, initiating the fan, or the lake was too shallow to permit deltaic deposits to form (see Cornish, 2017).

\section{Stage 2 (Figure 8-2/8-3)}

Following continued advance of the ice in Glen Spean/lower Glen Roy, the lake level in Glen Roy rises to $325 \mathrm{~m}$ which destabilizes the Turret ice margin, causing it to retreat, in turn allowing lake water to overtop the fan. Lithological Unit 1a (Table 2) is deposited as the ice retreats and is succeeded by Unit $1 \mathrm{~b}$, the distal glaciolacustrine sediments. The style of varve sedimentation in this unit is closely comparable to those of the middle and upper series of the Glen Turret Fan varves which form an integral part of the Lochaber Master Varve Chronology (LMVC - Palmer et al., 2010), which suggests that the varves of Unit $1 \mathrm{~b}$ at Turret Bank date to the middle of the Loch Lomond Stadial. During this phase, the ice front stabilised at the mouth of the Allt a' Chòmhlain valley (Figure 1); this retreat position is marked by depositional mounds and a flat terrace with a surface altitude of $325 \mathrm{~m}$, within which a kettle hole can be observed (Sissons, 2017; Cornish, 2017).

\section{Stage 3 (Figure 8-3)}

A further rise in lake level to $350 \mathrm{~m}$ causes the glacier to recede even further, and the $350 \mathrm{~m}$ shoreline to be formed within the Turret valley. It is presumed that distal glaciolacustrine deposition continued at the Turret Bank site.

\section{Stage 4 (Figure 8-4)}

The sediments in Unit 1c are severely contorted which suggests a significant change in depositional environment. This might reflect the impact of sudden lake lowering from 350 to $325 \mathrm{~m}$, but is more likely to result from the reduction in water level from 325 to $260 \mathrm{~m}$, as this would have led to down-cutting into the fan, and a shallowing of the lake basin in lower Glen Turret. It is proposed that the gully on the southern side of the fan was incised, probably very rapidly, at this time, with down-cutting halted by the rock bar at $244.44 \mathrm{~m} \mathrm{OD}$, which would have formed the overflow for the shallow basin in lower Glen Turret. Infill of the basin by sediment to the altitude of the rock bar appears to have been achieved by shortly after $\sim 10.83 \mathrm{ka}$, given the stratigraphic position of the Askja-S Tephra (Figure 6). 


\section{Stage 5 (Figure 8-5/8-6)}

Once the basin filled with sediment to the level of the rock bar, the Turret floodplain was established, with the river probably meandering across the lake infill until exiting through the gully, but capable of building floodplain deposits on the Turret valley floor, including gravel bars and terraces, during flood events (Figure 2).

The above scenario is considered the simplest integration of the local geomorphological, lithostratigraphical, pollen-stratigraphical and tephrochronological evidence. The alternative morphostratigraphic hypothesis that the moraines associated with the Turret fan, and the fan itself, were formed at an earlier period (i.e. during retreat of the Late Devensian ice sheet), requires an additional level of complexity for which there is currently no supporting evidence. In any case, it raises questions about the geomorphological context at the time. For example, if the moraines and the fan are of pre-Loch Lomond Stadial age, then after the ice margin retreated, did the Turret cut the gully at that time, down to the level of the rock bar at $244.44 \mathrm{~m}$ OD? If so, the basin would surely have infilled with older sediment, and therefore lack the capacity to accommodate the early Holocene sequence reported here. If, on the other hand, entrenchment of the gully was restricted to an altitude significantly higher than that of the rock step, then presumably fluvial terraces would have been excavated or deposited to this higher level within Glen Turret, and graded to this higher level, but there is no evidence for this. A second point is that, if there was no glacier occupying the Turret basin at the start of the Loch Lomond Stadial, then the basin would have been submerged throughout the entire history of the 260, 325 and 350 m lakes, and therefore should contain a varve record that corresponds with the full sequence of the LMVC (Palmer et al., 2010). The fact that the sequence (i) contains varves of the middle and late Stadial only, (ii) the varved deposits are intermittent, and (iii) they inter-bed with diamicton material, favours the interpretation presented here. A third point deserves comment, and that is the observation that the Turret moraines are subdued, more so than is usual for moraines assigned to the Loch Lomond Stadial in the Scottish Highlands, which has been used to argue for an older age, with the subdued morphology of the moraines perhaps the result of periglacial alteration during the Loch Lomond Stadial (Boston et al., 2013; Boston and Lukas, 2017). However, the situation in the Turret-Roy confluence is quite unique, because these moraines, as well the upper surface of the fan, were first submerged beneath lake waters up to 80-90 m deep, and subsequently met the full force of lake drainage floodwaters that swept over them, as the lakes dropped in level from 350 to $260 \mathrm{~m}$. A morphostratigraphic approach may therefore not apply in this instance.

\section{Conclusions}


The stratigraphic sequence preserved at the Turret Bank site in lower Glen Turret reflects changing sedimentary dynamics in the valley as a glacier of Loch Lomond Stadial age receded from its limit at the Turret fan. The Turret fan was probably formed when the glacier stood at its terminus. With the retreat of the glacier, waters of the 325 and $350 \mathrm{~m}$ lake flooded into Glen Turret, as reflected in a series of glaciolacustrine varves preserved in the Turret Bank sequence: these accord in form and micromorphological detail with those assigned to the middle and late Stadial in a master varve sequence and chronology developed for Glen Roy (Palmer et al., 2010). These were succeeded conformably by sediments of early Holocene age, demonstrated by pollen stratigraphy and a record of the Askja-S Tephra within the pollen sequence, dated to $10.83 \mathrm{ka}$. There is no evidence of deposits that pre-date the Stadial.

The above interpretation supports the conclusion reached by Lowe and Cairns in 1991, but is based on a better-resolved stratigraphic sequence and the first independent age estimate for the Turret Bank sequence. It remains, however, a conclusion based on probabilistic grounds, with uncertainties that deserve further exploration. For example, the evidence is based on a single core sequence only, and it is possible that a longer sedimentary sequence, perhaps with pre-Stadial deposits, exists in other parts of the valley. The dimensions of the former lake basin are not known. There is a need, therefore, for more extensive surveys using power-driven coring devices, perhaps preceded by seismic studies to establish the bathymetry of the former basin. Secondly, the varved record reported here is intermittent and more complex than varve sequences exposed on the distal edges of the Glen Turret Fan (GTF) and on other fans in Glen Roy. At Turret Bank, this may reflect complications induced by sediment accumulating in a separate depocentre to that of the Roy basin, in which the GTF varved sediments were deposited. More continuous and less disturbed varved deposits may exist in other parts of the former Turret lake basin. Thirdly, the early Holocene sequence extends over a depth interval of almost $2 \mathrm{~m}$; with a higher sample resolution than reported here, this sequence could potentially support one of the best resolved early Holocene pollen-stratigraphic records in Scotland, while it also contains a complex tephrostratigraphical record that has not yet been fully explored. With regard to the latter, the possibility that the Katla-derived tephra shards (section 5.6) represent both the Vedde Ash and Abernethy Tephra isochrons could help to refine the chronology of the lower part of the sequence, but making this distinction will be far from straightforward (see MacLeod et al., 2015).

The main conclusion of this paper - that the Turret Fan was formed during the Loch Lomond Stadial - is open to falsification, but awaits the discovery of definitive supporting evidence. 


\section{Acknowledgements}

JL thanks the Leverhulme Trust for financial support for some of the field and analytical analyses reported here (Emeritus Fellowship project EM-2014-025). The authors gratefully acknowledge the cordial co-operation of the Braeroy Estate, upper Glen Roy, and especially lain Stewart (the Head Stalker), for permitting the field operations on which this study was based, and the NERC (Natural Environment Research Council) for granting permission to access and use digital mapping data (NEXTMap imagery) supplied through Intermap Technologies Inc. We thank Chao Yuan Chen for help with preparing the images, lan Matthews, Dorothy Weston and the 2014-15 cohort of MSC Quaternary Science students for field assistance, Roger Cornish for providing some of the photographs and two reviewers of an earlier version of this submission (Kevin Edwards and Douglas Peacock) for their very helpful comments. 


\section{References}

Bendle, J.M., Palmer, A.P., Carr, S.J. 2015. A comparison of micro-CT and thin section analysis of Lateglacial glaciolacustrine varves from Glen Roy, Scotland. Quaternary Science Reviews 114, 61-77.

Benn, D.I., Lowe, J.J., Walker, M.J.C. 1992. Glacier response to climatic change during the Loch Lomond Stadial and early Flandrian: geomorphological and palynological evidence from the Isle of Skye, Scotland. Journal of Quaternary Science, 7, 125144.

Benn, D.I., Evans, D.J.A., 2008. A Younger Dryas ice cap to the north of Glen Roy: a new perspective on the origin of the Turret Fan. In: Palmer, A.P., Lowe, J.J., Rose, J. (Eds.), The Quaternary of Glen Roy and Vicinity: Field Guide. Quaternary Research Association, London, pp. 158-161.

Blockley SPE, Pyne-O'Donnell SDF, Lowe JJ, Matthews IP, Stone A, Pollard AM, Turney CSM, Molyneux E. 2005. A new and less destructive laboratory procedure for the physical separation of distal glass tephra shards from sediments. Quaternary Science Reviews 24, 1952-1960.

Boston, C.M., Lukas, S. 2017. Evidence for restricted Loch Lomond Stadial plateau ice in Glen Turret and implications for the age of the Turret Fan. Proceedings of the Geologists' Association (in this issue).

Boston, C.M., Lukas, S., Carr, S.J., 2013. Overview of Younger Dryas Glaciation in the Monadhliath Mountains. In: Boston, C.M., Lukas, S., Merritt, J.W., (Eds.), The Quaternary of the Monadhliath Mountains and the Great Glen: Field Guide. Quaternary Research Association, London, pp. 41-48.

Boston, C.M., Lukas, S., Carr, S.J. 2015. A Younger Dryas plateau icefield in the Monadhliath, Scotland, and implications for regional palaeoclimate. Quaternary Science Reviews 108, 139-162.

Bronk Ramsey, C., Housley, R.A., Lane, C.S., Smith, V.C., Pollard, A.M. 2015. The RESET tephra database and associated analytical tools. Quaternary Science Reviews 118, 33-47. 
Brooks, S.J., Matthews I.P., Birks, H.H., \&Birks, H.J.B. 2012a. High resolution Lateglacial and early-Holocene summer air temperature record from Scotland inferred from chironomid assemblages. Quaternary Science Reviews 41, 67-82.

Cornish, R. (2017). Origin of the gravel fans in upper Glen Roy, Lochaber, Scotland. Proceedings of the Geologists' Association (in this issue).

Davies, S. M. 2015. Cryptotephras: the revolution in correlation and precision dating, Journal of Quaternary Science, 30, 114-130.

Davies, S.M., Wastegård, S., Wohlfarth, B. 2003. Extending the limits of the Borrobol Tephra to Scandinavia and detection of new early Holocene tephras. Quaternary Research 59, 345-352.

Davies, S.M., Wohlfarth, B., Wastegård, S., Andersson, M., Blockley, S., Possnert, G. 2004. Were there two Borrobol Tephras during the early Lateglacial period: implications for tephrochronology? Quaternary Science Reviews 23, 581-589.

Dawson, A.G., Lowe, J.J., Walker, M.J.C. 1987. The nature and age of the debris accumulation at Gribun, western Mull, Scottish Inner Hebrides. Scottish Journal of Geology, 23, 149162.

Hall, M., Hayward, C. 2014. Preparation of micro- and crypto-tephras for quantitative microbeam analysis. Journal of the Geological Society of London 398, 21-28.

Hayward, C., 2011. High spatial resolution electron probe microanalysis of tephras and melt inclusions without beam-induced chemical modification. Holocene 22, 119-125.

Hesse, M., Waha, M. 1989. A new look at the acetolysis method. Plant Systematics and Evolution 163, 147-152.

Housley, R., Lane, C.S., Cullen, V.L., Weber, M.-J., Reide, F., Gamble, C.S., Brock, F. 2012. Icelandic volcanic ash from the Late-glacial open-air archaeological site of Ahrenshöft LA 58 D, North Germany. Journal of Archaeological Science 39, 708-716. 
Juggins, S. 2007. C2 User Guide: Software for Ecological and Palaeoecological Data Analysis and Visualisation, Version 1.5. University of Newcastle (http://www.campus.ncl.ac.uk/staff/Stephen.Juggins/software/C2Home.htm)

Kelly, T.J., Hardiman, M., Lovelady, M., Lowe, J.J., Blockley, S.P.E. 2017. Scottish early Holocene vegetation dynamics based on pollen and tephra records from Inverlair and Loch Etteridge, Inverness-shire. Proceedings of the Geologists' Association (in this issue)

Lane, C.S., Blockley, S.P.E., Bronk Ramsey, C., Lotter, A.F., 2011. Tephrochronology and absolute centennial scale synchronisation of European and Greenland records for the last glacial to interglacial transition: a case study of Soppensee and NGRIP. Quaternary International 246, 145-156.

Lane, C.S., De Klerk, P., Cullen, V.L., 2012a. A tephrochronology for the Lateglacial palynological record of the Endinger Bruch (Vorpommern, north-east Germany). Journal of Quaternary Science 27, 141-149.

Lane, C.S., Blockley, S.P.E., Mangerud, J., Smith, V.C., Lohne, Ø.S., Tomlinson, E.L., Matthews, I.P., Lotter, A.F. 2012b. Was the 12.1 ka Icelandic Vedde Ash one of a kind? Quaternary Science Reviews 33, 87-99.

Lane, C.S., Brauer, A., Blockley, S.P., Dulski, P. 2013. Volcanic ash reveals timetransgressive abrupt climate change during the Younger Dryas. Geology 41, 1251-1254.

Lilja, C., Lind, E.M., Morén, B., Wastegård, S., 2013. A Lateglacial - early Holocene tephrochronology for SW Sweden. Boreas 42, 544-554.

Lind, E.M., Wastegård, S. 2011. Tephra horizons contemporary with short early Holocene climate fluctuations: new results from the Faroe Islands. Quaternary International 246, 157167.

Lind, E.M., Wastegård, S., Larsen, J.J. 2013. A Late Younger Dryas-Early Holocene tephrostratigraphy for Fosen, Central Norway. Journal of Quaternary Science 28, 803-811.

Lind, E.W., Lilja, C., Wastegård, S., Pearce, N. 2016. Revisiting the Borrobol Tephra. Boreas 45, 629-643. 
Lowe, J.J. 2016. Volcanic ash stratigraphy: an emerging dating tool helping to refine the glacial history of Scotland during the Late Devensian. Scottish Geographical Journal, 132, 171-176.

Lowe, J.J., Cairns, P., 1991. New pollen-stratigraphic evidence for the deglaciation and lake drainage chronology of the Glen Roy-Glen Spean area. Scottish Journal of Geology 27, 4156.

Lowe, J.J., Walker, M.J.C. 1979. Pollen analyses, radiocarbon dates and the deglaciation of Rannoch Moor, Scotland, following the Loch Lomond Advance. In R.A. Cullingford et al. (eds.), Timescales in Geomorphology, Wiley, London \& New York, 247259.

Lowe, J.J., Walker, M.J.C. 1986. Flandrian environmental history of the Island of Mull, Scotland. II. Pollen analytical data from sites in western and northern Mull. New Phytologist, 103, 417436.

MacLeod, A., Matthews, I.P., Lowe, J.J., Palmer, A.P., Albert, P.G. 2015. A second tephra isochron for the Younger Dryas period: the Abernethy Tephra. Quaternary Geochronology 28, 1-11.

Matthews, I. P., Birks, H. H., Bourne, A. J., Brooks, S. J., Lowe, J. J., MacLeod, A., PyneO'Donnell, S. D. F. 2011. New age estimates and climatostratigraphic correlations for the Borrobol and Penifiler Tephras: evidence from Abernethy Forest, Scotland. Journal of Quaternary Science, 26, 247-252.

Palmer, A.P., Rose, J., Lowe, J.J., MacLeod, A. 2010. Annually resolved events of Younger Dryas glaciation in Lochaber (Glen Roy and Glen Spean), Western Scottish Highlands. Journal of Quaternary Science 25 (4), 581-596.

Palmer, A.P., Rose, J., Rasmussen, S.O. 2012. Evidence for phase-locked changes in climate between Scotland and Greenland during GS-1 (Younger Dryas) using micromorphology of glaciolacustrine varves from Glen Roy. Quaternary Science Reviews 36, 114-123.

Palmer, A.P., Lowe, J.J. 2017. Dynamic landscape changes in Glen Roy and vicinity, west Highland Scotland, during the Last Termination: a synthesis. Proceedings of the Geologists' Association (in this issue). 
Peacock, J.D.,1986. Alluvial fans and an outwash fan in upper Glen Roy, Lochaber. Scottish Journal of Geology 22, 347-366.

Pilcher, J., Bradley, R.S., Francus, P., Anderson, L., 2005. A Holocene tephra record from the Lofoten Islands, Arctic Norway. Boreas 34, 136-156.

Pyne-O’Donnell, S.D.F., Blockley, S.P.E., Turney, C.S.M., Lowe, J.J. 2008. Distal volcanic ash layers in the Lateglacial Interstadial (GI-1): problems of stratigraphic discrimination. Quaternary Science Reviews 27, 72-84

Ramírez-Rojas, I. 2015. The Early Holocene pollen sequence of the Turret Bank, Scottish Highlands; Glen Roy and the timing of local glaciation. Unpublished MSc Thesis, Royal Holloway University of London.

Sissons, J.B. 2017. The lateglacial lakes of Glens Roy, Spean and vicinity (Lochaber District, Scottish Highlands). Proceedings of the Geologists' Association (2016).

Sissons, J.B., Cornish, R., 1983. Fluvial landforms associated with ice-dammed lake drainage in upper Glen Roy, Scotland. Proceedings of the Geologists' Association 94, 4552.

Timms, R.G.O., Matthews, I.P., Palmer, A.P., Candy, I. \& Abel, L. 2016. A high-resolution tephrostratigraphy from Quoyloo Meadow, Orkney, Scotland: implications for the tephrostratigraphy of NW Europe during the Last Glacial-Interglacial Transition. Quaternary Geochronology (in Early View).

Turney CSM, Harkness DD, Lowe JJ. 1997. The use of microtephra horizons to correlate Late-glacial lake sediment successions in Scotland. Journal of Quaternary Science 12, 525531.

Turney, C. S. M., Lowe, J. J., Davies, S. M., Hall, V., Lowe, D. J., Wastegård, S., Hoek, W. Z., Alloway, B. 2004. Tephrochronology of Last Termination sequences in Europe: a protocol for improved analytical precision and robust correlation procedures (a joint SCOTAVINTIMATE proposal). Journal of Quaternary Science, 19, 111-120. 
Turney, C.S.M., Van Den Burg, K., Wastegård, S., Davies, S.M., Whitehouse, N.J., Pilcher, J.R., Callaghan, C., 2006. North European last glacial-interglacial transition (LGIT; 15-9 ka) tephrochronology: extended limits and new events. Journal of Quaternary Science 21, 335345.

Walker, M.J.C., Lowe, J.J. $\quad$ 1981. Postglacial environmental history of Rannoch Moor. III. Early and mid Flandrian pollen stratigraphic data from sites on western Rannoch Moor and near Fort William. Journal of Biogeography, 8, 475491.

Walker, M.J.C. \& Lowe, J.J. 1982. Lateglacial and early Flandrian chronology of the Isle of Mull, Scotland. Nature, 296, 558561.

Wastegård, S. 2002. Early to middle Holocene silicic tephra horizons from the Katla volcanic system, Iceland: new results from the Faroe Islands. Journal of Quaternary Science 17, 723730.

Wulf, S., Dräger, N., Ott, F., Serb, J., Appelt, O., Guơmundsdóttir, E., van den Bogaard, C., Słowiński, M., Błaszkiewicz, M., Brauer, A. 2016. Holocene tephrostratigraphy of varved sediment records from Lakes Tiefer See (NE Germany) and Czechowskie (N Poland). Quaternary Science Reviews 132, 1-14. 


\section{Figure captions}

Figure 1. Location detail. 1a. Location of the study area and of some key features referred to in text, in particular the generalised maximum glacial limits of the Loch Lomond Readvance. TBL - Turret Bank site. LLE - Loch Etteridge site. 1b. The study area showing maximum glacier limits in Glen Roy and vicinity, after Sissons (2017). 1c and 1d. Geomorphological features close to the Turret-Roy confluence (1 km grid squares), showing location and form of key features referred to in text (unmarked in 1c). The prominent parallel lines on the hillside are the 325 and 350 m shorelines. Note that the $325 \mathrm{~m}$ shoreline is clearly marked on the NE side of Glen Turret, but fades in the vicinity of the up-valley limit of the arcuate moraine ridges, whereas the $350 \mathrm{~m}$ shoreline continues further up the Turret valley. The NEXTMap DEMs shown here are provided courtesy of the Natural Environment Research Council (NERC) and Intermap Technologies.

Figure 2. A. Google Earth image of Turret-Roy confluence illustrating the extent of incision into, and removal of material from, the Turret Fan. See text for further detail. B. Photograph facing SE taken from the present floodplain of the River Turret (foreground) showing the steep 'inner' (NW) margin of the Turret Fan, the opening to the Turret Gorge and the location of the Turret Bank core site. C. View eastwards from the right bank of the River Turret (foreground), close to its confluence with the River Roy, showing fluvial terraces cut into the Turret Fan, the surface of which is at $\sim 257 \mathrm{~m}$ OD in this locality. Photographs B and C supplied by Roger Cornish. See text for further detail.

Figure 3. A. Lithofacies units for the Turret Bank core, including down-core variations in loss-on-ignition (\%), magnetic susceptibility $\left(\times 10^{-5} \mathrm{SI}\right.$ Units) and tephra shard distributions for $5 \mathrm{~cm}$ interval rangefinder samples and $1 \mathrm{~cm}$ interval sampling. B. Photomicrographs (note scale bars) of example sedimentary structures associated with lithofacies units $1 \mathrm{~b}$ to $2 \mathrm{~b}$ (Table 2) in plane-polarised light except for the cross-polarised light image of unit $1 \mathrm{~b}$ (575 $\mathrm{cm})$. C. Two cross-polarised light photomicrographs of varves from the Glen Turret Fan (GTF) sequence: a) is from the upper part of the GTF section, where the overall thickness of the varves is $>3 \mathrm{~mm}$, with winter clay layers (red bar) thicker than summer silt layers (yellow bar); b) is from the lower GTF section which has thinner varves (0.5 $-1.5 \mathrm{~mm}$ ) with summer layers thicker than winter ones. These characteristics show clear similarity with the varves identified in the Turret Bank sequence (see text for further details). D. Representative frequency and cumulative particle size data for the units defined in Table 2 and described in the text. 
Figure 4. Relative pollen diagram (scales below curves are percentage of total land pollen) for Core A of the Turret Bank sediment sequence, showing main taxa only. The key characteristics of the local pollen assemblage zones (Ipaz) are summarised in Table 3.

Figure 5. Plots comparing the geochemical measurements obtained from the data listed in Table 4 with the chemical envelopes for close-matching Lateglacial and early Holocene tephras: (A) total alkali v. silica (TAS plot); (B) expansion of the data shown in $A$; (C) CaO v. $\mathrm{FeO}$ data; (D) $\mathrm{TiO}_{2}$ v. $\mathrm{Al}_{2} \mathrm{O}_{3}$ data. The chemical envelopes are based on the following sources: Borrobol type - Lind et al., 2013, 2016; Timms et al., 2016; Askja-S - Davies et al., 2003; Pilcher et al., 2005; Turney et al., 2006; Lind and Wastegård 2011; Lane et al., 2013; Wulf et al., 2016; Kelly et al., 2017; Timms et al., 2016; Abernethy Tephra - Matthews et al., 2011; MacLeod et al. 2015; Vedde Ash - Matthews et al., 2011; Lane et al., 2012b; MacLeod et al., 2015; Timms et al., 2016.

Figure 6. Synthesis of the litho-, pollen- and tephrostratigraphical evidence obtained from the Turret Bank sequence.

Figure 7. View taken from the $325 \mathrm{~m}$ shoreline near Allt Dearg (NN347928) across the westward limit of the Turret Fan (foreground). Linear ridges mark the margin of the fan (A-B), beyond which is the Turret floodplain, with the River Turret at the foot of the slope in the middle distance (small 'o' marks the floodplain surface, close to the Turret Bank site). The far flank of the Turret valley shows evidence of landslips (C) and landslip scars (D), which could have resulted from paraglacial relaxation following the retreat of a glacier, which terminated at this locality.

Figure 8. Schematic illustration of the sequence of events in the area of the Glen TurretGlen Roy confluence during the Loch Lomond Stadial, based on the evidence presented in this paper. Note that the precise positions of the margins of the inferred glacial limits, and the exact timing of glacial advance and retreat, are not yet clear. The scheme is therefore approximate, serving to aid visualisation of the order of events considered to be reflected in the Turret Bank sedimentary sequence. The scheme incorporates some aspects of the evidence presented by Sissons (2017) and Cornish (2017) for the location of the Gloy-Turret glacier maximum and subsequent retreat stages (Stages 1 to 4), and by Boston et al. (2015) and Boston and Lukas (2017) for advance of ice into the upper Turret catchment from a plateau icefield that occupied the western valleys of the Monadhliath Mountains (Stages 2 and 3). In Stage 5 the main Roy lakes have drained and a small lake is impounded by the 
Turret Fan. Rapid incision leads to the cutting of the gully at the southern margin of the fan, down to the rock step at $244.44 \mathrm{~m}$ OD (Stage 5 ). The small lake subsequently infills with sediment, a process that was virtually complete by $10.83 \mathrm{ka}$ (the age of the Askja-S Tephra), leading to the formation of a flood-plain in the Turret valley (Stage 6).

\section{Table captions}

Table 1. Data obtained from MPI-DING (A) and Lipari obsidian (B) international glass standards used to calibrate the geochemical measurements reported in Table 3.

Table 2. Summary of the lithological variations observed in the sequence recovered from Core A, Turret Bank, and the main lithostratigraphic units and sub-units identified. Depths are relative to the site datum with $0 \mathrm{~cm}$ at $246.91 \mathrm{~m}$ OD.

Table 3. Key characteristics of the pollen-stratigraphic sequence shown in Figure 4. LPAZ - local pollen assemblage zone; TB - Turret Bank; depths are relative to the site datum (246.91 m OD).

Table 4. Major oxide concentrations (raw data) of volcanic glass shards recovered from the Turret Bank sediment sequence 